\title{
Müzik Öğretmeni Adaylarının Duygusal Zekâ ve Eleştirel Düşünme Eğilimlerinin İncelenmesi*
}

\section{An Analysis on Emotional Intelligence and Critical Thinking Trends of Music Teacher Candidates}

Onur Mermer

Öğretmen, TED Özel Atakent Anadolu Lisesi

email: onurmermer91@gmail.com DORCID ID: https://orcid.org/0000-0003-2186-9736

\author{
Ajda Aylin Can \\ Doç. Dr., Marmara Üniversitesi, Atatürk Eğitim Fakültesi, Müzik Eğitimi Anabilim Dalı \\ email: acan@marmara.edu.tr (DORCID ID: https://orcid.org/0000-0001-9332-0385
}

*Bu çalışma, Marmara Üniversitesi Eğitim Bilimleri Enstitüsünde yapılan "Müzik Öğretmeni Adaylarının Duygusal Zekâ ve Eleştirel Düşünme Eğilimleri Arasındaki İlişkinin İncelenmesi” adlı yüksek lisans tezinden türetilmiştir.

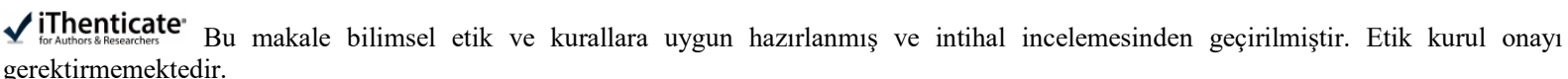

Attf (APA 6)/To cite this article

Mermer, O., \& Can, A. A., (2020). Müzik öğretmeni adaylarının duygusal zekâ ve eleştirel düşünme eğilimlerinin incelenmesi. Atatürk Üniversitesi Güzel Sanatlar Enstitüsü Dergisi, 26(45), 674-690. doi: https://doi.org/10.35247/ataunigsed.777656

Makale Gönderim Tarihi/Received: 06/08/2020

Makale Kabul Tarihi/Accepted: 08/10/2020

Makale Yayın Tarihi/Published: 22/10/2020

Research Article/Araştırma Makalesi

Öz

$\mathrm{Bu}$ araștırmada, Müzik Eğitimi Anabilim Dalı öğrencilerinin duygusal zekâ (DZ) ve eleştirel düşünme eğilimleri (EDE) ile alt boyutları arasındaki ilisski incelenmiștir. Tarama modelli olan bu araştırma, 6 farklı üniversiteden rastgele seçilmiş Müzik Eğitimi Anabilim Dalı son sinıfta öğrenim gören toplam 204 öğrenci ile gerçekleşmiștir. Araştırmada DZ' yi belirlemek amacıyla, Türkçeye uyarlamasını Saltukoğlu, Tatar ve Tok'un yaptığı 41 maddelik "Schutte Duygusal (Gözden Geçirilmiș) Zekâ Ölçeği", EDE' yi saptamak üzere, Türkçeye uyarlamasını Kökdemir'in yaptı̆̆ 51 maddelik "California Eleștirel Düsünme Eğilimi Ölçeği", demografik özellikleri belirlemek üzere araștırmacı tarafından yapılan 10 maddelik "Kișisel Bilgi Formu" kullanılmıstır. Veri analizinde, frekans, yüzde dağılım, t-testi, Mann-Whitney $U$ testi, post-hoc Scheffe testi, post-hoc MannWhitney $U$ testi, Pearson Korelasyon Katsayısı değerleri alınmıștır. Elde edilen bulgulara göre, genel EDE düzeyi ile genel DZ düzeyi arasında "orta" güçlükte, anlamlı ve pozitif bir ilişki olduğu saptanmıștır. Müzik öğretmeni adaylarının, EDE düzeyleri ile ilgili demografik özelliklerinin öğrencilerin yaşı, mezun oldukları lise ve DZ ile ilgili bilgi düzeyi açısından anlamlı farklılaşmaya neden olduğu, cinsiyet açısından ise kısmen veya tamamen anlamlı bir farklılaşmaya neden olmadığı sonucuna ulaşılmışıtır.

Anahtar kelimeler: Müzik Öğretmeni Adayları, Duygusal Zekâ, Eleştirel Düşünme Eğilimi

\begin{abstract}
In this study, the relationship between emotional intelligence and critical thinking trends of music education students and their lower dimensions was examined. The research in which screening model was used was conducted with a total of 204 students who were randomly selected from 6 different universities in the last year of the Department of music education. The 41-item "Schutte emotional (revised) Intelligence Scale", adapted to Turkish by Saltukoglu, Tatar and Tok, and the 51-item "California critical thinking trend scale", adapted to Turkish by Kokdemir, were used to determine emotional intelligence, and the 10-item "Personal Data Form" developed by the researcher was used to determine demographic characteristics. Data analysis frequency, percentage distribution, t-test, Mann-Whitney U-test, post-hoc Scheffe test post-hoc Mann-Whitney U test, Pearson correlation coefficient values were taken. According to the findings, there was a significant and positive association between the general level of critical thinking and the general level of emotional intelligence with "moderate" difficulty. It is concluded that he demographic characteristics of the music teacher candidates related to the EDE levels caused a significant difference in terms of the age of the students, the high school they graduated from and the level of knowledge about DZ, but did not cause a partially or completely significant difference in terms of gender.
\end{abstract}

Keywords: Music Teacher Candidates, Emotional Intelligence, Critical Thinking Trend

\section{Giriş}

Eğitim, önceden belirlenmiş amaçlarla birlikte, insanları yönlendirme ve yetiştirme ile bu iki kavramın ilmini ve tekniğini öğreten bir bilim dalıdır (Çelikkaya, 2009, s. 28). Eğitim alan kişilerin olumlu davranışlar kazanması, mesleki bilgi ve tekniklerini öğrenerek üretken olması amaçlanmaktadır (Türkoğlu, 2005, s. 14).

Bireylerin, toplum yaşantısına uyum sağlayabilmeleri, özgüven sahibi olabilmeleri, kendilerini iyi ifade edebilmeleri ve entelektüel yönlerinin gelişimine katkı sağlayabilmeleri için önem taşıyan bir etkenin müzik eğitimi olduğu ifade edilmektedir.

Uçan'a (2015) göre müzik eğitimi, temelde bir müziksel davranış kazandırma, bir müziksel davranış değiştirme veya bir müziksel davranış değişikliği oluşturma sürecidir ve süreç dâhilinde bireyin yaşantısından yola çıkılması önemlidir. Müzik eğitimi yaygın ve örgün eğitim kurumlarında gerçekleştirilmektedir. 
Değişime bağlı olarak yapılan bilimsel araştırmalar pek çok alanda olduğu gibi eğitimde de bazı kavramları beraberinde getirmiştir. Duygusal zekâ (bundan sonra "DZ" ile gösterilecektir) da bunlardan biridir. Özellikle müzik eğitiminde önemle ele alınan bir konu olarak kabul ve ilgi görmektedir. Bireylerin, bir düşünceyi ve olguyu sorgulaması, sentezlemesi ve onu doğru bir şekilde aktarabilmesi önemlidir ve bu noktada zekâ kavramı düşünme ve düşünceyi geliştirecek etkenlerden biridir.

Duygu, bireyin düşünme ve düşüncesini etkileyen önemli bir unsurdur. Duyguları, bir his ve bu hisse özel belirli düşünceler ve psikolojik haller olarak tanımlamaktadır (Goleman, 2018, s. 373-374). Bu nedenle psikolojik ve biyolojik durumumuzla değişkenlik gösteren duygu çeşitliliği, insan yaşamında büyük rol oynayarak, bireyin yaşantısına yön verebilmektedir.

Goleman'a göre akılcı ve duygusal olmak üzere, iki farklı beyin, zekâ ve zihnimizin olduğu, bireyin hayatını nasıl devam ettireceği bunların bütünü tarafından belirlendiği ifade edilmektedir ve bu nedenle zekâ katsayısı (IQ) ile birlikte DZ (EQ) da önem kazanmaktadır (Goleman, 2018, s. 57). Ayrı düşünülmemesi gereken bu iki kavram, DZ (EQ) olgusunu ön plana çıkarmaktadır. Duygu ve zekâ birbirini tamamlayıcı bir yapıya sahiptir ve DZ da tam bu noktada tamamlayıcılığı savunmaktadır (Tufan, 2011, s. 2).

Son yıllarda DZ ile ilgili araştırmalar, ilişkili olabileceği alanlar ile ilgili farkındalıkları da beraberinde getirmiştir. Kişinin kendini ifade edebilmesi, kişiler arası ilişkilerde kendini kabullendirebilmesi, kendisi ve çevresindekiler için doğru ve net kararlar verip empati kurabilmesi tüm bu ilişkilerin müzik zekâsı ve yeteneği ile bağlantılı olabileceği fikrini ortaya çıkarmıştır (Pektaş, 2013, s. 3). Bu nedenle DZ, sosyal, kültürel ve kişiler arası ilişkilerde önemli bir yere sahip olmaya başlamıştır.

Duygu ve düşünce birbiriyle ilişki içindedir ve ayrı düşünülmemelidir. Kişi yaşamı boyunca birçok olayla karşı karşıya kalarak duygu ve düşüncelerini kullanmaktadır ve bu olaylara verilen duygusal tepkiler, geçmiş yaşamlarından edinilmiş tecrübelerle gelişmektedir (Dutoğlu ve Tuncel., 2008, s. 16). Bu nedenle kişide negatif ya da pozitif duygu durumlarına yol açabilir.

Kişideki duygu ve düşüncelerin birbirinden ayrı düşünülmemesi gerektiği ve bu duygu ve düşünceleri farklı bakış açılarıyla değerlendiren kişilerin eleştirel düşünme eğilimine (bundan sonra "EDE” ile gösterilecektir) sahip oldukları düşünülebilir. EDE'nin bu noktada önem kazandığı ve bu nedenle eleştirel düşünce ile DZ arasında önemli bir ilişki olduğu söylenebilmektedir. Bireylerin kendi düşüncelerinin farkında olması, başkalarının düşüncelerini anlayıp sorgulaması ve bu düşünceleri kendi bakış açısıyla ele alabilmesi ve yorumlayabilmesi için eleştirel düşünme biçimine sahip olması bu noktada bir gereklilik olarak ifade edilebilir.

Norris'e (1985) göre, eleştirel düşünme, eğitimin bir idealidir ve EDE'nin bireylere kazandırılması onların sorumluluk duygusunu geliştirmeye, entelektüel, ahlaki ve duygusal sorumluluklarını yerine getirmelerine imkân sağlayabilmektedir. Eğitim kurumları, sergileyecekleri durum ile EDE'nin öğrencilere kazandırılması noktasında önemlidir. Bilgileri sentezleyen, yorumlayabilen ve topluma uyum sağlayabilen bireyler yetiştirmek, okulların önemli görevlerinden biridir.

Eleştirel düşünme ile bağlantılı olarak müzik eğitiminde, müziğin bireyin bir bütün olarak yetişmesine hizmet eden temel alanlardan biri olduğu dikkate alındığında öğretmenlerin öğrencilere karşı olan duygusal ve davranışsal tutumlarının önemli olduğu düşünülmektedir. Diğer zekâ alanlarındaki başarıları da pozitif yönde etkileyen müzikle ilgilenen bireylere, kendilerini geliştirebilecekleri ve rahatça ifade edebilecekleri zihinsel ve sanatsal bir ortam hazırlamaktadır (Çuhadar, 2006, s. 486-497).

Çağdaş eğitimle birlikte ezbere dayalı eğitim azalacak ve öğrenciler daha çok sorgulayan, araştıran ve sentezleyen bir eğitim modeline geçeceklerdir. Bu nedenle öğretmenlerin sergileyeceği davranışlar önemlidir. Öğretmenler, öğrencilerin daha aktif bir şekilde derslere katılmasına ve soru sormasına olanak sağlayan ve öğrencilerin verilen bilgileri eleştirel bir bakış açısıyla ele alması gerektiğini savunan eğitmenler olarak görev almalıdırlar (Demir, 2006, s. 74-75). Bu bağlamda öğretmenlere birçok sorumluluk düşmektedir.

Bir öğretmenden beklenen önemli özelliklerden biri öğrencisi ile empati kurabilmesidir. Öğretmenlerin öğrencileri ile empati kurabilmesinin yanında eleştirel düşünme becerilerinin yüksek olması da yaşadıkları durumu kontrol edebilmeleri ve yönetebilmelerini sağlamaktadır. Bu nedenle müzik öğretmeni adaylarının yaşantılarında duygularını kontrol edebilmeleri ve yönetebilmeleri mesleki açıdan aranan bir beceri olarak görülmektedir. Duygusal becerilerin gelişimi, kişilerin gelişim çağında daha kolay ilerleyen bir süreçtir. Bu noktada ilgili okullarda verilecek duygusal eğitimin önemli olduğu ifade edilebilir. Okullardaki eğitimin genel olarak grup iş birliği ve dayanışmasından yoksun olduğu, rekabeti teşvik edici olmakla birlikte, duyguları ve ilişkileri ihmal ettiği görülmektedir (Gürşen Otacıŏlu, 2009, s. 88). Öğretmenler, öğrencilerin karşılaşabilecekleri sıkıntılı durumlarda gösterecekleri davranışlarla öğrencilerin sosyal dinamiklere uyum sağlayabilmelerine yardımcı olabilirler, bu tür durumlarla nasıl başa çıkmaları gerektiği konusunda yol gösterebilirler. 
Müzik öğretmenliğinin mesleki niteliklerini genel kültür, alan bilgisi, pedagojik formasyon, eleştirel düşünme ve iletişim becerileri oluşturmaktadır. Bu niteliklerden birinin eksik olması veya olmaması durumu, müzik öğretmenliği mesleki niteliklerinden önemli bir boyutun eksik olması anlamına gelebilmektedir. Etkili bir müzik öğretmeninin, mesleki nitelikleri oluşturan bu boyutlara yeterli düzeyde sahip olması gerekmekte ve bu noktada müzik eğitiminin eleştirel düşünme amacı, öğrencilerin var olan müzik yeteneklerini daha iyi kullanabilmelerine ve daha iyi müzisyen olmalarına imkân tanıyabilmektedir. Bu noktada müzik eğitiminin eleştirel düşünme amacı, öğrencilerin var olan müzik yeteneklerini daha iyi kullanabilmelerine ve daha iyi müzisyen olabilmelerine imkân tanıyabilmektedir. Eleştirel düşünce ile geliştirilen müzik dersleri hayal gücü, zekâ ve yaratıcılıkla doğru orantılıdır. Müzik derslerinde çocuklara çeşitli deneyimler kazandıran öğretmenlerin, günümüzde düşünme odaklı bir eğitimin öneminden yola çıkarak eleştirel eğitim bilimine ilgi duydukları görülmektedir (Akyüzlüer, 2014, s. 112). Literatürde yer alan bu bilgilerin önemi doğrultusunda yapılan araștırmada, müzik öğretmeni adaylarının DZ ve EDE arasındaki ilişkinin ne yönde olduğu konusu araştırmanın problemini ortaya koymaktadır.

\subsection{Amaç}

Bu araştırmanın amacı, müzik öğretmeni adaylarının DZ ile EDE arasında bir ilişki olup olmadığını saptamaktır.

$\mathrm{Bu}$ amaçla birlikte aşağıdaki sorulara cevap aranmaktadır:

1. Müzik öğretmeni adaylarının DZ gelişimleri demografik özelliklerine (cinsiyet, yaş, mezun olduğu lise türü) göre farklılaşmakta mıdır?

2. Müzik öğretmeni adaylarının EDE'nin gelişimi demografik özelliklerine (cinsiyet, yaş, mezun olduğu lise türü) göre farklılaşmakta mıdır?

3. Müzik öğretmeni adaylarının DZ ve EDE arasında bir ilişki var mıdır?

\section{Yöntem}

\subsection{Araştırmanın Modeli}

Araştırmada, genel tarama modellerinden ilişkisel tarama modeli kullanılmıştır. Karasar'a (2017) göre ilişkisel tarama modelleri, iki veya daha çok değişken arasında birlikte veya değişimin varlığını ve/veya derecesini belirlemeye çalışan araştırma modelleridir.

\subsection{Evren ve Örneklem}

Araştırmanın evrenini 2018-2019 eğitim-öğretim yılında Türkiye'deki Eğitim Fakülteleri Güzel Sanatlar Eğitimi Bölümü Müzik Eğitimi Anabilim Dalı'nda öğrenim gören son sınıf müzik öğretmeni adayları oluşturmaktadır. Araştırmanın örneklem grubunu, Türkiye'deki 5 bölgede toplam 6 üniversitenin 2018-2019 eğitim-öğretim y1lında Eğitim Fakülteleri Güzel Sanatlar Eğitimi Bölümü Müzik Eğitimi Anabilim Dalı'nda öğrenim gören son sınıf öğrencilerinden 129'u kadın ve 75'i erkek toplam 204 müzik öğretmeni adayı oluşturmuştur. Örneklem grubuna gerekli izinlerin alınabildiği üniversiteler dahil edilmiştir. Müzik öğretmeni adaylarının demografik özellikleri Tablo 1-Tablo 5'de sunulmuştur.

Tablo 1

Müzik Öğretmeni Adaylarının Yaşa Göre Dağılımları

\begin{tabular}{|c|c|c|c|c|}
\hline Yaş & $\mathbf{f}$ & $\%$ & $\%$ Gec. & $\%$ Yığ. \\
\hline 19 yaş ve altı & 15 & 7.4 & 7.4 & 7.4 \\
\hline 20 ve üstü & 189 & 92.6 & 92.6 & 100.0 \\
\hline Toplam & 204 & 100.0 & 100.0 & \\
\hline
\end{tabular}

Araştırmaya katılan müzik öğretmeni adaylarının \%7,4’ü 19 yaş ve altı, \%92,6’sı ise 20 yaş ve üstüdür.

Tablo 2

Müzik Öğretmeni Adaylarının Cinsiyete Göre Dağılımları

\begin{tabular}{|c|c|c|c|c|}
\hline Cinsiyet & f & $\%$ & $\%_{\text {Gec. }}$ & $\%$ Y Yığ. \\
\hline Kadın & 129 & 63.2 & 63.2 & 63.2 \\
\hline Erkek & 75 & 36.8 & 36.8 & 100.0 \\
\hline Toplam & 204 & 100.0 & 100.0 & \\
\hline
\end{tabular}

Öğretmen adaylarının \%63,2’si kadın ve \%36,8'i erkektir.

Tablo 3

Müzik Öğretmeni Adaylarının Mezun Oldukları Lise Türüne Göre Dağılımları

\begin{tabular}{|c|c|c|c|c|}
\hline Mezun Olunan Lise & $\mathbf{f}$ & $\%$ & $\%_{\text {Gec. }}$ & $\%$ Y Yı̆. \\
\hline Konservatuvar & 7 & 3.4 & 3.4 & 3.4 \\
\hline GSL & 161 & 78.9 & 78.9 & 82.4 \\
\hline Diğer & 36 & 17.6 & 17.6 & 100.0 \\
\hline Toplam & 204 & 100.0 & 100.0 & \\
\hline
\end{tabular}


Müzik öğretmeni adaylarının büyük bir bölümü, \%78,9 ile Güzel Sanatlar Lisesi mezunudur. Öğretmen adaylarının \%3,4’ü bir konservatuvardan mezunken kalan \%17,6’sı diğer bir lise türünden mezundur.

Tablo 4

Müzik Öğretmeni Adaylarının EDE ile İlgili Bilgi Düzeylerine Göre Dağılımları

\begin{tabular}{lcccc}
\hline EDE ile İlgili Bilgi Düzeyi & f & $\mathbf{\%}$ & $\mathbf{\%}$ Gec. & \% Y Y.̆. \\
\hline Yetersiz & 52 & 25.5 & 25.5 & 25.5 \\
Biraz yeterli & 51 & 25.0 & 25.0 & 50.5 \\
Yeterli & 101 & 49.5 & 49.5 & 100.0 \\
Toplam & 204 & 100.0 & 100.0 & \\
\hline
\end{tabular}

Öğrencilerin \%25,5'i EDE ile ilgili bilgi düzeylerini yetersiz bulurken, \%25,0’i biraz yeterli ve \%49,5'i yeterli olarak belirtmektedir.

Tablo 5

Müzik Öğretmeni Adaylarının DZ ile İlgili Bilgi Düzeylerine Göre Dağılımları

\begin{tabular}{|c|c|c|c|c|}
\hline DZ ile İlgili Bilgi Düzeyi & f & $\%$ & $\%$ Gec. & $\%$ Yığ. \\
\hline Yetersiz & 42 & 20.6 & 20.6 & 20.6 \\
\hline Biraz yeterli & 49 & 24.0 & 24.0 & 44.6 \\
\hline Yeterli & 113 & 55.4 & 55.4 & 100.0 \\
\hline Toplam & 204 & 100.0 & 100.0 & \\
\hline
\end{tabular}

Öğrencilerin \%20,6's1 DZ ile ilgili bilgi düzeylerini yetersiz bulurken, \%24,0’ü biraz yeterli ve \%55,4'ü yeterli olarak görmektedir.

\subsection{Verilerin Toplanması}

Araştırmada üç veri toplama aracı kullanılmıştır. İlki müzik öğretmeni adaylarının DZ düzeylerini belirlemek üzere Saltukoğlu, Tatar ve Tok tarafindan (2011) Türkçeye uyarlanan 41 maddelik "Schutte Duygusal (Gözden Geçirilmiş) Zekâ Ölçeği” dir. Üç alt boyuttan/faktörden (İyimserlik/Ruh Halinin Düzenlenmesi, Duyguların Değerlendirilmesi ve Duyguların Kullanımı) oluşan 5'li Likert tipinde tasarlanmış olan ölçeğin maddeleri, çalışmaya katılan müzik öğretmeni adayları tarafından "Kesinlikle katılmıyorum" (1) ile "Kesinlikle katılıyorum" (5) seçeneklerinden biri seçilerek değerlendirilmektedir. Ölçek ve alt boyutlarından alınan ortalama puanın yüksekliği, bireylerin o DZ alanına ilişkin düzeyini göstermektedir. Ölçme aracındaki seçenekler arasındaki aralıkların eşit olduğu varsayımından hareketle iki aralık arası değer 0,80 olarak hesaplanmıştır $\left(4_{\text {aralık }} / 5_{\text {seçenek }}=0,80\right)$.

Tablo 6'da “DZ Ölçeği”nin bu araştırma için geçerlik ve güvenirliğini kontrol etmek üzere Alfa modeli ile maddeler arası korelasyona bağlı uyum değerleri hesaplanmıştır.

Tablo 6

DZ Ölçeğine İlişkin Güvenirlik Analizi

\begin{tabular}{|c|c|c|c|c|}
\hline Boyut & Madde & $\begin{array}{l}\text { Madde-Toplam } \\
\text { Korelasyonu }\end{array}$ & $\begin{array}{c}\text { Madde Silindiğinde Güvenirlik } \\
\text { Katsayısı }(\alpha)\end{array}$ & Genel Güvenirlik Katsayısı (a) \\
\hline \multirow{21}{*}{ 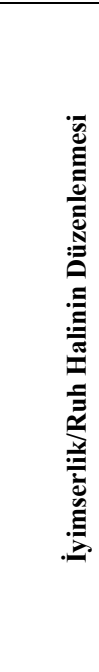 } & eq1 & 0.491 & 0.877 & \multirow{21}{*}{0.883} \\
\hline & eq2 & 0.627 & 0.874 & \\
\hline & eq5 & 0.432 & 0.879 & \\
\hline & eq7 & 0.668 & 0.873 & \\
\hline & eq9 & 0.544 & 0.876 & \\
\hline & eq11 & 0.533 & 0.876 & \\
\hline & eq15 & 0.303 & 0.885 & \\
\hline & eq16 & 0.619 & 0.874 & \\
\hline & eq18 & 0.577 & 0.875 & \\
\hline & eq19 & 0.584 & 0.874 & \\
\hline & eq21 & 0.553 & 0.876 & \\
\hline & eq25 & 0.308 & 0.882 & \\
\hline & eq27 & 0.651 & 0.873 & \\
\hline & eq29 & 0.650 & 0.873 & \\
\hline & eq30 & 0.498 & 0.877 & \\
\hline & eq31 & 0.534 & 0.876 & \\
\hline & eq32 & 0,468 & 0,878 & \\
\hline & eq33 & 0,469 & 0,878 & \\
\hline & eq36 & 0,307 & 0,880 & \\
\hline & eq37 & 0,650 & 0,872 & \\
\hline & eq38 & 0,601 & 0,874 & \\
\hline
\end{tabular}


Tablo 6'nın devamı

\begin{tabular}{|c|c|c|c|c|}
\hline Boyut & Madde & $\begin{array}{c}\text { Madde-Toplam } \\
\text { Korelasyonu }\end{array}$ & $\begin{array}{l}\text { Madde Silindiğinde Güvenirlik } \\
\text { Katsayısı ( } \alpha)\end{array}$ & Genel Güvenirlik Katsayısı ( $\alpha$ ) \\
\hline \multirow{13}{*}{ 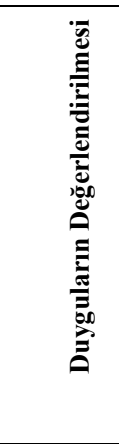 } & eq3* & 0,385 & 0,787 & \\
\hline & eq6* & 0,416 & 0,784 & \\
\hline & eq $8 *$ & 0,418 & 0,784 & \\
\hline & eq12* & 0,317 & 0,796 & \\
\hline & eq17* & 0,561 & 0,771 & \\
\hline & eq $22 *$ & 0,379 & 0,787 & \\
\hline & eq24* & 0,429 & 0,783 & \\
\hline & eq26* & 0,357 & 0,789 & \\
\hline & eq $28 *$ & 0,389 & 0,788 & \\
\hline & eq35* & 0,391 & 0,787 & \\
\hline & eq39* & 0,492 & 0,778 & \\
\hline & eq $40^{*}$ & 0,537 & 0,775 & \\
\hline & eq $41 *$ & 0,548 & 0,772 & \\
\hline \multirow{7}{*}{ 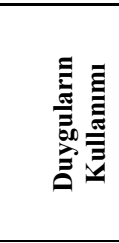 } & eq4 & 0,309 & 0,571 & \multirow{7}{*}{0,691} \\
\hline & eq10 & 0,397 & 0,521 & \\
\hline & eq13 & 0,390 & 0,523 & \\
\hline & eq14 & 0,307 & 0,571 & \\
\hline & eq20 & 0,305 & 0,571 & \\
\hline & eq23 & 0,318 & 0,593 & \\
\hline & eq34 & 0,427 & 0,513 & \\
\hline \multicolumn{2}{|c|}{ Duygusal Zekâ Ölçeği } & & & 0,794 \\
\hline
\end{tabular}

“DZ Ölçeği”nin ilk alt boyutu, Iyimserlik/Ruh Halinin Düzenlenmesi için güvenirlik katsayısı (Cronbach's Alfa a) 0,883; ikinci alt boyutu Duyguların Değerlendirilmesi için 0,796 ve üçüncü alt boyutu Duyguların Kullanımı için 0,691 olarak hesap edilmiştir. Bu değerler "DZ Ölçeği”"nin alt boyutlarında yer alan maddeler arasında güvenirliğin (iç-tutarlılığın) yüksek olduğunu göstermektedir. Herhangi bir madde alt boyutlardan silindiğinde güvenirlik katsayısının (Cronbach Alfa) yükselmeyeceği görüldüğünden (sondan önceki sütun), alt boyutlardan herhangi bir maddenin çıkarılmasına gerek olmadığı görülmektedir. Iyimserlik/Ruh Halinin Düzenlenmesi alt boyutuna ilişkin madde-toplam korelasyon katsayılarının 0,303 ile 0,668; Duyguların Değerlendirilmesi alt boyutuna ilişkin madde-toplam korelasyon katsayılarının 0,317 ile 0,561; Duyguların Kullanımı alt boyutunun korelasyon katsayılarının 0,305 ile 0,427 arasında olduğu hesaplanmış ve maddeler ile ilgili alt boyutlar arasında yeterli düzeyde ilişki ( $r \geq 0,30)$ olduğu görülmüştür.

“DZ Ölçeği”nin iç-tutarlılığı için tüm maddeleri (41 maddesi) birlikte ve tek boyutlu olarak incelendiğinde ise genel güvenirlik katsayısının 0,794 olduğu bulunmuştur. Bu da "Duygusal Zekâ Ölçeğì"nin tek boyutlu olarak da kullanılabileceğini ve oldukça güvenilir olduğunu göstermektedir.

Sonuç olarak, "DZ Ölçeği”nin güvenirlik (iç-tutarlılık) düzeyinin bu çalışma için de yeterli olduğu anlaş1lmaktadır.

Araştırmanını ikinci veri toplama aracı müzik öğretmeni adaylarının eleştirel düşünme düzeylerini ölçmek üzere Kökdemir (2013) tarafından Türkçe'ye çevrilen 51 maddelik “California EDE Ölçeği” (bundan sonra EDE Ölçeği olarak anılacaktır) dir. Altı alt boyuttan/faktörden oluşan 6’lı Likert tipinde düzenlenen ölçeğin maddeleri, çalışmaya katılan müzik öğretmeni adayları tarafından "Hiç katılmıyorum" (1) ile "Tamamen katılıyorum" (6) seçeneklerinden biri seçilerek değerlendirilmektedir ve ölçeğin geneli için iç-tutarlılık katsayısı 0,88 olarak hesaplanmıştır.

Tablo 7'de “EDE Ölçeği”nin bu çalışma için güvenirliği yine bir madde analizi ile Cronbach's Alfa katsayılarına bakılarak kontrol edilmiştir.

Tablo 7

EDE Ölçeğine İlişkin Güvenirlik Analizi

$\left.\begin{array}{clcc}\hline \text { Boyut } & \text { Madde } & \begin{array}{c}\text { Madde-Toplam } \\ \text { Korelasyonu }\end{array} & \begin{array}{c}\text { Madde Silindiğinde Güvenirlik Katsayısı } \\ (\boldsymbol{\alpha})\end{array} \\ \hline \text { el02 } & 0.321 & 0.625 \\ \text { el03 } & 0.449 & 0.578 \\ (\boldsymbol{\alpha})\end{array}\right)$


Tablo 7'nin devamı

\begin{tabular}{|c|c|c|c|c|}
\hline Boyut & Madde & $\begin{array}{c}\text { Madde-Toplam } \\
\text { Korelasyonu }\end{array}$ & $\begin{array}{l}\text { Madde Silindiğinde Güvenirlik Katsayısı } \\
(\alpha)\end{array}$ & $\begin{array}{c}\text { Genel Güvenirlik Katsayısı } \\
(\alpha)\end{array}$ \\
\hline \multirow{12}{*}{ 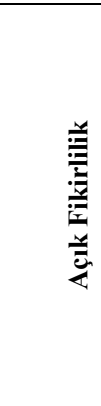 } & el07 & 0.330 & 0.815 & \multirow{12}{*}{0.818} \\
\hline & el05* & 0.347 & 0.815 & \\
\hline & el15* & 0.516 & 0.801 & \\
\hline & el18* & 0.427 & 0.809 & \\
\hline & $\mathrm{el} 22 *$ & 0.502 & 0.802 & \\
\hline & el33* & 0.370 & 0.814 & \\
\hline & el36* & 0.425 & 0.809 & \\
\hline & $\mathrm{el} 41 *$ & 0.522 & 0.800 & \\
\hline & el43* & 0.412 & 0.810 & \\
\hline & $\mathrm{el} 45^{*}$ & 0.738 & 0.778 & \\
\hline & el47* & 0.469 & 0.805 & \\
\hline & $\mathrm{el} 50^{*}$ & 0.553 & 0.797 & \\
\hline \multirow{9}{*}{ 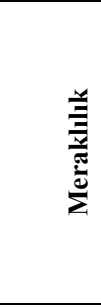 } & el01 & 0.331 & 0.723 & \multirow{9}{*}{0.726} \\
\hline & el08 & 0.326 & 0.716 & \\
\hline & el30 & 0.460 & 0.691 & \\
\hline & el31 & 0.469 & 0.689 & \\
\hline & el32 & 0.492 & 0.685 & \\
\hline & el34 & 0.453 & 0.692 & \\
\hline & el38 & 0.368 & 0.707 & \\
\hline & el42 & 0.512 & 0.682 & \\
\hline & el46 & 0.395 & 0.720 & \\
\hline \multirow{7}{*}{ 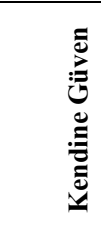 } & el14 & 0.311 & 0.651 & \multirow{7}{*}{0.668} \\
\hline & el29 & 0.493 & 0.596 & \\
\hline & el35 & 0.394 & 0.629 & \\
\hline & el39 & 0.332 & 0.645 & \\
\hline & el44 & 0.420 & 0.619 & \\
\hline & el48 & 0.327 & 0.668 & \\
\hline & el51 & 0.437 & 0.617 & \\
\hline \multirow{7}{*}{ 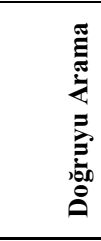 } & el06* & 0.339 & 0.541 & \multirow{7}{*}{0.663} \\
\hline & el11* & 0.370 & 0.488 & \\
\hline & el20* & 0.338 & 0.504 & \\
\hline & el25* & 0.385 & 0.525 & \\
\hline & el27* & 0.304 & 0.554 & \\
\hline & el28* & 0.392 & 0.522 & \\
\hline & el49* & 0.370 & 0.530 & \\
\hline \multirow{6}{*}{ 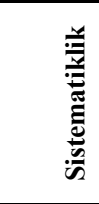 } & el04 & 0.319 & 0.602 & \multirow{6}{*}{0.699} \\
\hline & el09* & 0.416 & 0.515 & \\
\hline & el10 & 0.318 & 0.613 & \\
\hline & el19* & 0.340 & 0.552 & \\
\hline & el2 $1 *$ & 0.405 & 0.522 & \\
\hline & el23* & 0.469 & 0.495 & \\
\hline \multicolumn{4}{|c|}{ Eleștirel Düşünme Eğilimi Ölçeği } & 0.860 \\
\hline
\end{tabular}

*Ters (olumsuz yüklemli) madde/ifade.

“EDE Ölçeği”nin ilk alt boyutu Analitiklik için güvenirlik katsayısı (Cronbach's Alfa $\alpha$ ) 0,629; ikinci alt boyutu Açık Fikirlilik için 0,818; üçüncü alt boyutu Meraklılık için 0,726; dördüncü alt boyutu Kendine Güven için 0,668; beşinci alt boyutu Doğruyu Arama için 0,663 ve altıncı alt boyutu Sistematiklik için 0,699 olarak hesap edilmiştir. Bu değerler, "EDE Ölçeği”"nin altı alt boyutunu meydana getiren maddeler arasında güvenirliğin (iç-tutarlılığın) oldukça güvenilir derecede olduğunu göstermektedir. Sondan önceki sütun incelendiğinde görüleceği için ölçek alt boyutlarından çıkarılması halinde güvenirliği yükseltecek bir madde yoktur. Maddeler ile boyutların toplam maddeleri arasındaki ilişkilere bakıldığında; Analitiklik alt boyutuna ilişkin madde-toplam korelasyon katsayılarının 0,304 ile 0,495; Açık Fikirlilik alt boyutuna ilişkin madde-toplam korelasyon katsayılarının 0,330 ile 0,738; Meraklılık alt boyutuna ilişkin madde-toplam korelasyon katsayılarının 0,326 ile 0,512; Kendine Güven alt boyutuna ilişkin madde-toplam korelasyon katsayılarının 0,311 ile 0,493; Doğruyu Arama alt boyutuna ilişkin madde-toplam korelasyon katsayılarının 0,304 ile 0,392 ve Sistematiklik alt boyutunun korelasyon katsayılarının 0,318 ile 0,469 arasında olduğu hesaplanmış ve maddeler ile ilgili alt boyutlar arasında yeterli düzeyde ilişki $(\mathrm{r} \geq 0,30)$ olduğu görülmüştür.

“EDE Ölçeği”nin 51 maddesi birlikte (tek boyutlu olarak) analize dâhil edildiğinde ise genel güvenirlik katsayısının 0,860 olduğu bulunmuştur. Bu da “EDE Ölçeğì"nin tek boyutlu olarak da kullanılabileceğini ve yüksek derecede güvenilir olduğunu göstermektedir.

Sonuç olarak, "EDE Ölçeği”nin güvenirlik (iç-tutarlılık) düzeyinin bu çalışma için de yeterli olduğu anlaşılmaktadır. 


\subsection{Verilerin Analizi}

Müzik öğretmeni adaylarının, DZ ve EDE düzeylerini araştırmak üzere, ölçek ve alt boyutlarına ilişkin puanların ortalaması ve standart sapma (ss) değeri, anlamlı fark olup olmadığını araştırmak üzere bağımsız/ilişkisiz gruplar t-testi, non-parametrik bağımsız/ilişkisiz gruplar Mann-Whitney $U$ testi, Kruskal-Wallis $H$ testi, post-hoc MannWhitney $U$ testi ve Pearson momentler çarpımı korelasyonu katsayıları hesaplanmıştır.

\section{Bulgular}

\subsection{Müzik Öğretmeni Adaylarının DZ Düzeylerine Yönelik Bulgular}

Tablo 8

Müzik Öğretmeni Adaylarının DZ Düzeylerine İlişkin Betimsel İstatistikler (N=204)

\begin{tabular}{lrrr}
\hline Boyut/Ölçek & $\overline{\mathbf{X}}$ & \multicolumn{1}{c}{ Ss } & Düzey \\
\hline İyimserlik/Ruh halinin düzenlenmesi & 3.78 & 0.57 & Yüksek \\
Duyguların değerlendirilmesi & 3.56 & 0.64 & Yüksek \\
Duyguların kullanımı & 2.70 & 0.64 \\
\hline DZ (Genel) & $\mathbf{3 . 3 5}$ & Orta & $\mathbf{0 . 3 1}$ \\
\hline
\end{tabular}

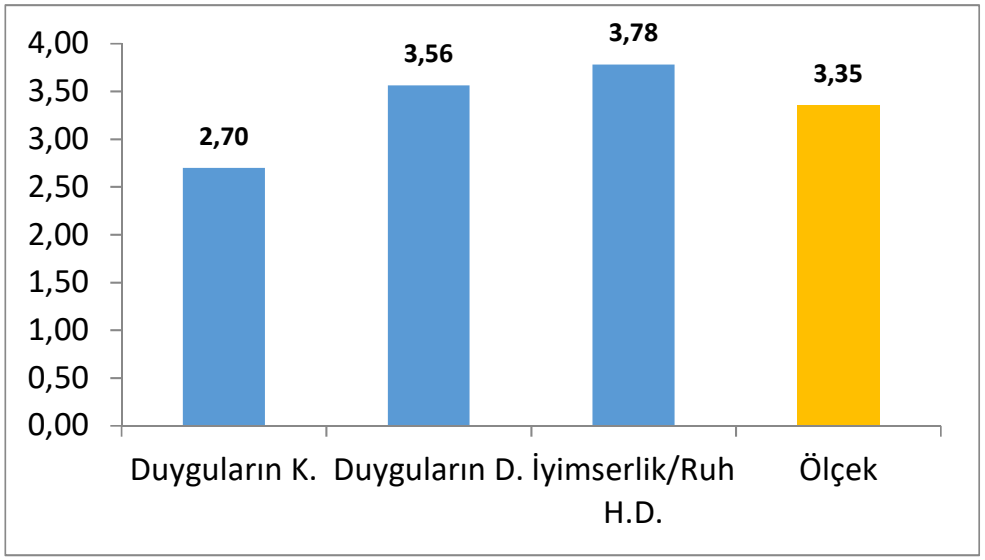

Şekil 1. Müzik öğretmeni adaylarının DZ düzeylerine ilişkin sıralı ortalama puanlar

Tablo 8 ve Şekil 1'de araştırmaya katılan müzik öğretmeni adaylarının “DZ Ölçeği”nin geneli ve alt boyutlarından aldıkları ortalama puanlar verilmiştir. Buna göre; araştırmaya katılan müzik öğretmeni adaylarının (genel) DZ'leri orta düzeydedir $\left(\bar{X}_{\text {Ölçek }}=3,35 \pm 0,31\right.$; "Fikrim yok"/“Orta” düzeyinde). Sonuçlar birlikte değerlendirildiğinde, araştırmaya katılan müzik öğretmeni adaylarının kendi algılarına göre DZ düzeylerinin orta seviyede olduğu anlaşılmaktadır.

Tablo 9

Müzik Öğretmeni Adaylarının DZ Düzeylerinin Yaşa Göre Karşılaştırılmasına Yönelik Mann-Whitney U Testi $(\mathrm{N}=204)$

\begin{tabular}{|c|c|c|c|c|c|c|c|c|}
\hline \multirow{2}{*}{ Ölçek } & \multirow{2}{*}{ Yaş } & \multicolumn{3}{|c|}{ Betimsel İst. } & \multicolumn{3}{|c|}{ Mann-Whitney U } & \multirow{2}{*}{ Etki Düzeyi $(r)$} \\
\hline & & $n$ & Sira Ort. & Stralar Top. & $\boldsymbol{U}$ & $Z$ & $p$ & \\
\hline $\begin{array}{l}\text { İyimserlik/Ruh halinin } \\
\text { düz. }\end{array}$ & $\begin{array}{l}\geq 19 \\
20 \geq\end{array}$ & $\begin{array}{c}15 \\
189\end{array}$ & $\begin{array}{c}63.83 \\
105.57\end{array}$ & $\begin{array}{c}957.50 \\
19952.50\end{array}$ & 837.50 & -2.64 & $0.008 * *$ & 0.18 \\
\hline $\begin{array}{l}\text { Duyguların } \\
\text { değerlendirilmesi }\end{array}$ & $\begin{array}{l}\geq 19 \\
20 \geq\end{array}$ & $\begin{array}{c}15 \\
189\end{array}$ & $\begin{array}{l}106.73 \\
102.16\end{array}$ & $\begin{array}{c}1601.00 \\
19309.00\end{array}$ & 1354.00 & -0.29 & 0.773 & - \\
\hline Duyguların kullanımı & $\geq 19$ & 15 & 97.43 & 1461.50 & 1341.50 & -0.35 & 0.729 & - \\
\hline DZ (Genel) & $\begin{array}{l}\geq 19 \\
20 \geq\end{array}$ & $\begin{array}{c}15 \\
189\end{array}$ & $\begin{array}{c}77.10 \\
104.52\end{array}$ & $\begin{array}{c}1156.50 \\
19753.50\end{array}$ & 936.50 & -2.13 & $0.033^{*}$ & 0.15 \\
\hline
\end{tabular}

Tabloda görüldüğü üzere, yaş değişkeni, ölçeğin bir alt boyutu (İyimserlik/Ruh halinin düzenlenmesi) ve geneli bakımından anlamlı bir farklılaşmaya neden olmaktadır. 
Tablo 10

Müzik Öğretmeni Adaylarının DZ Düzeylerinin Cinsiyete Göre Karşılaştırılmasına Yönelik T-Testi (N=204)

\begin{tabular}{|c|c|c|c|c|c|c|c|c|}
\hline \multirow{2}{*}{ Ölçek } & \multirow{2}{*}{ Cinsiyet } & \multicolumn{3}{|c|}{ Betimsel İst. } & \multicolumn{3}{|c|}{ t-Testi } & \multirow{2}{*}{ Etki Düzeyi $(d)$} \\
\hline & & $n$ & $\overline{\mathbf{X}}$ & Ss & $t$ & sd & $\boldsymbol{P}$ & \\
\hline \multirow{2}{*}{ İyimserlik/Ruh halinin düzenlenmesi } & Kadın & 129 & 3.80 & 0.59 & \multirow{2}{*}{0.83} & \multirow{2}{*}{202} & \multirow{2}{*}{0.410} & \multirow{2}{*}{-} \\
\hline & Erkek & 75 & 3.74 & 0.52 & & & & \\
\hline \multirow{2}{*}{ Duyguların değerlendirilmesi } & Kadın & 129 & 3.63 & 0.62 & \multirow{2}{*}{2.01} & \multirow{2}{*}{202} & \multirow{2}{*}{$0.046^{*}$} & \multirow{2}{*}{0.29} \\
\hline & Erkek & 75 & 3.45 & 0.66 & & & & \\
\hline \multirow{2}{*}{ Duyguların kullanımı } & Kadın & 129 & 2.66 & 0.68 & \multirow{2}{*}{1.08} & \multirow{2}{*}{202} & \multirow{2}{*}{0.284} & \multirow{2}{*}{-} \\
\hline & Erkek & 75 & 2.76 & 0.57 & & & & \\
\hline \multirow{2}{*}{ DZ (Genel) } & Kadın & 129 & 3.37 & 0.33 & \multirow{2}{*}{1.11} & \multirow{2}{*}{202} & \multirow{2}{*}{0.267} & \multirow{2}{*}{-} \\
\hline & Erkek & 75 & 3.31 & 0.28 & & & & \\
\hline
\end{tabular}

${ }^{*} p<.05, * * p<.01$

Tabloda görüldüğü üzere, cinsiyet değișkeni, ölçeğin sadece duyguların değerlendirilmesi alt boyutu bakımından anlamlı bir farklılaşmaya neden olmaktadır.

Tablo 11

Müzik Öğretmeni Adaylarının DZ Düzeylerinin Mezun Oldukları Lise Türüne Göre Karşılaştırılmasına Yönelik Kruskal-Wallis H Testi $(\mathrm{N}=204)$

\begin{tabular}{|c|c|c|c|c|c|c|c|c|}
\hline \multirow{2}{*}{ Boyut/Ölçek } & \multirow{2}{*}{ Mezun Olunan Lise } & \multicolumn{2}{|c|}{ Betimsel İst. } & \multicolumn{3}{|c|}{ Kruskal-Wallis } & \multirow{2}{*}{ M-W } & \multirow{2}{*}{ Etki $(d)$} \\
\hline & & $\mathbf{n}$ & Sira Ort. & $\mathbf{X}^{2}$ & sd & $\mathbf{p}$ & & \\
\hline \multirow{3}{*}{$\begin{array}{l}\text { İyimserlik/Ruh halinin } \\
\text { düzenlenmesi }\end{array}$} & Konservatuvar (1) & 7 & 129.57 & \multirow{3}{*}{8.17} & \multirow{3}{*}{2} & \multirow{3}{*}{$0.017 *$} & \multirow{3}{*}{1 ile 3} & \multirow{3}{*}{0.36} \\
\hline & GSL (2) & 161 & 106.66 & & & & & \\
\hline & Diğer (3) & 36 & 78.63 & & & & & \\
\hline \multirow{3}{*}{$\begin{array}{l}\text { Duyguların } \\
\text { değerlendirilmesi }\end{array}$} & Konservatuvar (1) & 7 & 123.57 & \multirow{3}{*}{7.78} & \multirow{3}{*}{2} & \multirow{3}{*}{$0.032 *$} & \multirow{3}{*}{1 ile 3} & \multirow{3}{*}{0.34} \\
\hline & GSL (2) & 161 & 105.65 & & & & & \\
\hline & Diğer (3) & 36 & 84.31 & & & & & \\
\hline \multirow{3}{*}{ Duyguların kullanımı } & Konservatuvar (1) & 7 & 98.21 & \multirow{3}{*}{1.18} & \multirow{3}{*}{2} & \multirow{3}{*}{0.554} & \multirow{3}{*}{-} & \multirow{3}{*}{-} \\
\hline & GSL (2) & 161 & 104.77 & & & & & \\
\hline & Diğer (3) & 36 & 93.17 & & & & & \\
\hline \multirow{3}{*}{ DZ (Genel) } & Konservatuvar (1) & 7 & 154.29 & \multirow{3}{*}{14.83} & \multirow{3}{*}{2} & \multirow{3}{*}{$0.001 * *$} & \multirow{3}{*}{1 ile 2,3} & \multirow{3}{*}{0.52} \\
\hline & GSL (2) & 161 & 106.71 & & & & & \\
\hline & Diğer (3) & 36 & 103.61 & & & & & \\
\hline
\end{tabular}

Tabloda görüldüğü üzere, mezun olunan lise, ölçeğin hem geneli hem de iki alt boyutu (İyimserlik/Ruh halinin düzenlenmesi ve Duyguların değerlendirilmesi) bakımından da anlamlı bir farklılaşmaya neden olmaktadır.

Tablo 12

Müzik Öğretmeni Adaylarının DZ Düzeylerinin EDE ile İlgili Bilgi Düzeyine Göre Karşılaştırılmasına Yönelik Anova Testi $(\mathrm{N}=204)$

\begin{tabular}{|c|c|c|c|c|c|c|c|c|}
\hline \multirow{2}{*}{ Boyut/Ölçek } & \multirow{2}{*}{$\begin{array}{l}\text { Eleștirel Düşünme İle İlgili } \\
\text { Bilgi Düzeyi }\end{array}$} & \multicolumn{3}{|c|}{ Betimsel İst. } & \multicolumn{2}{|c|}{ ANOVA } & \multirow{2}{*}{ Scheffe } & \multirow{2}{*}{ Etki $(\eta)$} \\
\hline & & $n$ & $\overline{\mathbf{X}}$ & Ss & $F$ & $P$ & & \\
\hline \multirow{3}{*}{$\begin{array}{l}\text { İyimserlik/Ruh halinin } \\
\text { düzenlenmesi }\end{array}$} & Yetersiz (1) & 52 & 3.61 & 0.59 & & & & \\
\hline & Biraz yeterli (2) & 51 & 3.66 & 0.61 & 3.15 & $0.045^{*}$ & 1,2 ile 3 & 0.17 \\
\hline & Yeterli (3) & 101 & 3.98 & 0.52 & & & & \\
\hline \multirow{3}{*}{$\begin{array}{l}\text { Duyguların } \\
\text { değerlendirilmesi }\end{array}$} & Yetersiz (1) & 52 & 3.43 & 0.67 & & & & \\
\hline & Biraz yeterli (2) & 51 & 3.58 & 0.63 & 1.69 & 0.188 & - & - \\
\hline & Yeterli (3) & 101 & 3.62 & 0.62 & & & & \\
\hline \multirow{3}{*}{ Duyguların kullanımı } & Yetersiz (1) & 52 & 2.77 & 0.66 & & & & \\
\hline & Biraz yeterli (2) & 51 & 2.68 & 0.65 & 0.37 & 0.693 & - & - \\
\hline & Yeterli (3) & 101 & 2.68 & 0.64 & & & & \\
\hline \multirow{3}{*}{ DZ (Genel) } & Yetersiz (1) & 52 & 3.30 & 0.32 & & & & \\
\hline & Biraz yeterli (2) & 51 & 3.30 & 0.33 & 2.23 & 0.110 & - & - \\
\hline & Yeterli (3) & 101 & 3.39 & 0.30 & & & & \\
\hline
\end{tabular}

Tabloda görüldüğü üzere, eleştirel düşünme ile ilgili bilgi düzeyi, ölçeğin sadece bir alt boyutu (İyimserlik/Ruh halinin düzenlenmesi) bakımından anlamlı bir farklılaşmaya neden olmaktadır. 
Tablo 13

Müzik Öğretmeni Adaylarının DZ Düzeylerinin DZ ile İlgili Bilgi Düzeyine Göre Karşılaştırılmasına Yönelik Anova Testi $(\mathrm{N}=204)$

\begin{tabular}{|c|c|c|c|c|c|c|c|c|}
\hline \multirow{2}{*}{ Boyut/Ölçek } & \multirow{2}{*}{ DZ ile İlgili Bilgi Düzeyi } & \multicolumn{3}{|c|}{ Betimsel İst. } & \multicolumn{2}{|c|}{ ANOVA } & \multirow{2}{*}{ Scheffe } & \multirow{2}{*}{ Etki $(\eta)$} \\
\hline & & $n$ & $\overline{\mathbf{X}}$ & Ss & $F$ & $p$ & & \\
\hline \multirow{3}{*}{$\begin{array}{l}\text { İyimserlik/Ruh } \\
\text { halinin düzenlenmesi }\end{array}$} & Yetersiz (1) & 42 & 3.66 & 0.57 & \multirow{3}{*}{1.32} & \multirow{3}{*}{0.270} & \multirow{3}{*}{-} & \multirow{3}{*}{-} \\
\hline & Biraz yeterli (2) & 49 & 3.76 & 0.58 & & & & \\
\hline & Yeterli (3) & 113 & 3.83 & 0.56 & & & & \\
\hline \multirow{3}{*}{$\begin{array}{l}\text { Duyguların } \\
\text { değerlendirilmesi }\end{array}$} & Yetersiz (1) & 42 & 3.35 & 0.68 & \multirow{3}{*}{4.47} & \multirow{3}{*}{$0.013 *$} & \multirow{3}{*}{1,2 ile 3} & \multirow{3}{*}{0.21} \\
\hline & Biraz yeterli (2) & 49 & 3.39 & 0.51 & & & & \\
\hline & Yeterli (3) & 113 & 3.77 & 0.65 & & & & \\
\hline \multirow{3}{*}{ Duyguların kullanımı } & Yetersiz (1) & 42 & 2.78 & 0.69 & \multirow{3}{*}{0.43} & \multirow{3}{*}{0.649} & \multirow{3}{*}{-} & \multirow{3}{*}{-} \\
\hline & Biraz yeterli (2) & 49 & 2.69 & 0.59 & & & & \\
\hline & Yeterli (3) & 113 & 2.68 & 0.65 & & & & \\
\hline \multirow{3}{*}{ DZ (Genel) } & Yetersiz (1) & 42 & 3.23 & 0.29 & \multirow{3}{*}{3.94} & \multirow{3}{*}{$0.025^{*}$} & \multirow{3}{*}{1,2 ile 3} & \multirow{3}{*}{0.17} \\
\hline & Biraz yeterli (2) & 49 & 3.27 & 0.31 & & & & \\
\hline & Yeterli (3) & 113 & 3.47 & 0.32 & & & & \\
\hline
\end{tabular}

Tabloda görüldüğü üzere, ölçeğin geneli ve bir alt boyutu bakımından (duyguların düzenlenmesi) anlamlı bir farklılaşmaya neden olmaktadır.

Tablo 14

Müzik Öğretmeni Adaylarının DZ Düzeylerinin Demografik Özelliklerine Göre Karşılaştırılmasına Yönelik Özet Tablo

\begin{tabular}{lccc}
\hline \multirow{2}{*}{ Değişken/Ölçek } & \multicolumn{2}{c}{ DZ Ölçeği } \\
\cline { 2 - 4 } & Iyimserlik/Ruh H.D. & Duyguların Değ. & Duyguların kullanımı \\
\hline Yaşlçek (Genel) \\
Cinsiyet & $* *$ & Fark yok & Fark yok \\
Mezun olunan lise & Fark yok & $*$ & Fark yok \\
EDE ile ilgili bilgi düzeyi & $*$ & $*$ & Fark yok \\
DZ ile ilgili bilgi düzeyi & $*$ & Fark yok yok & Fark yok \\
\hline
\end{tabular}

Fark $* p<.05, * * p<.01, * * * p<.001$ düzeyinde anlamlıdır.

Araştırmaya göre, müzik öğretmeni adaylarının DZ düzeylerinin demografik özelliklerine göre farklılaşmalarını özetlemek gerekirse (Tablo 14); öğrencilerin yaşı, mezun oldukları lise ve DZ ile ilgili bilgi düzeyi anlamlı farklılaşmaya neden olurken $(\mathrm{p}<.05)$, cinsiyet ve EDE ile ilgili bilgi düzeyi ise kısmen veya tamamen anlamlı bir farklılaşmaya neden olmamaktadır ( $\mathrm{p}>.05)$.

\subsection{Müzik Öğretmeni Adaylarının EDE Düzeylerine Yönelik Bulgular}

Tablo 15

Müzik Öğretmeni Adaylarının EDE Düzeylerine İlişkin Betimsel İstatistikler (N=204)

\begin{tabular}{|c|c|c|c|c|c|}
\hline Boyut/Ölçek & En Düşük & En Yüksek & $\overline{\mathbf{X}}$ & Ss & Düzey \\
\hline Analitiklik & 29 & 57 & 45.08 & 5.90 & Orta \\
\hline Açık fikirlilik & 19 & 58 & 39.28 & 8.69 & Düşük \\
\hline Meraklılık & 23 & 60 & 46.01 & 6.69 & Orta \\
\hline Kendine güven & 24 & 57 & 43.12 & 6.69 & Orta \\
\hline Doğruyu arama & 14 & 57 & 33.98 & 8.03 & Düşük \\
\hline Sistematiklik & 10 & 60 & 40.65 & 8.07 & Orta \\
\hline Ölçek & 194 & 320 & 247.87 & 27.86 & Orta \\
\hline
\end{tabular}

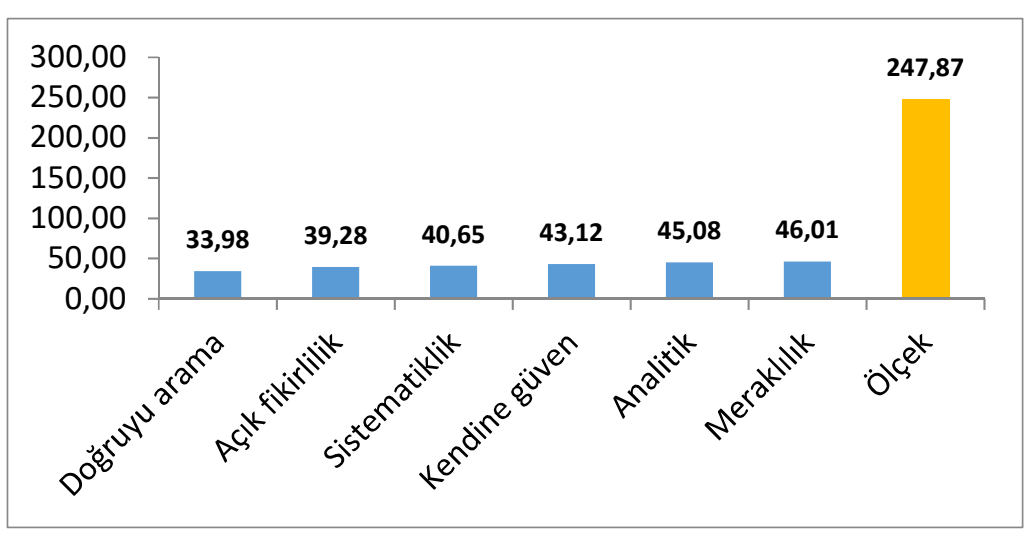

Şekil 2. Müzik öğretmeni adaylarının EDE düzeylerine ilişkin sıralı ortalama puanlar 
Tablo 15 ve Şekil 2'de araştırmaya katılan müzik öğretmeni adaylarının “EDE Ölçeği”nin geneli ve alt boyutlarından aldıkları ortalama puanlar verilmiştir. Buna göre; araştırmaya katılan müzik öğretmeni adaylarının (genel) EDE orta düzeydedir.

Araştırmaya katılan müzik öğretmeni adaylarının demografik özelliklerine bağlı olarak EDE düzeylerinde (puanlarında) farklılaşma olup olmadığı aşağıda incelenmiştir.

Tablo 16

Müzik Öğretmeni Adaylarının EDE Düzeylerinin Yaşa Göre Karşılaştırılmasına Yönelik Mann-Whitney U Testi $(\mathrm{N}=204)$

\begin{tabular}{|c|c|c|c|c|c|c|c|c|}
\hline \multirow{2}{*}{ Ölçek } & \multirow{2}{*}{ Yaş } & \multicolumn{3}{|c|}{ Betimsel İst. } & \multicolumn{3}{|c|}{ Mann-Whitney U } & \multirow{2}{*}{ Etki Düzeyi $(r)$} \\
\hline & & $n$ & Stra Ort. & Stralar Top. & $\boldsymbol{U}$ & $Z$ & $\boldsymbol{P}$ & \\
\hline \multirow{2}{*}{ Analitiklik } & $\geq 19$ & 15 & 57.90 & 868.50 & \multirow{2}{*}{748.50} & \multirow{2}{*}{-3.05} & \multirow{2}{*}{$0.002 * *$} & \multirow{2}{*}{0.22} \\
\hline & $20 \geq$ & 189 & 106.04 & 20041.50 & & & & \\
\hline \multirow{2}{*}{ Açık fikirlilik } & $\geq 19$ & 15 & 75.47 & 1132.00 & \multirow{2}{*}{1012.00} & \multirow{2}{*}{-1.82} & \multirow{2}{*}{0.069} & \multirow{2}{*}{-} \\
\hline & $20 \geq$ & 188 & 104.12 & 19574.00 & & & & \\
\hline \multirow{2}{*}{ Meraklılık } & $\geq 19$ & 15 & 58.40 & 876.00 & \multirow{2}{*}{756.00} & \multirow{2}{*}{-3.01} & \multirow{2}{*}{$0.003 * *$} & \multirow{2}{*}{0.21} \\
\hline & $20 \geq$ & 189 & 106.00 & 20034.00 & & & & \\
\hline \multirow{2}{*}{ Kendine güven } & $\geq 19$ & 15 & 85.40 & 1281.00 & \multirow{2}{*}{1161.00} & \multirow{2}{*}{-1.17} & \multirow{2}{*}{0.242} & \multirow{2}{*}{-} \\
\hline & $20 \geq$ & 189 & 103.86 & 19629.00 & & & & \\
\hline \multirow{2}{*}{ Doğruyu arama } & $\geq 19$ & 14 & 83.25 & 1165.50 & \multirow{2}{*}{1060.50} & \multirow{2}{*}{-1.24} & \multirow{2}{*}{0.215} & \multirow{2}{*}{-} \\
\hline & $20 \geq$ & 189 & 103.39 & 19540.50 & & & & \\
\hline \multirow{2}{*}{ Sistematiklik } & $\geq 19$ & 15 & 97.63 & 1464.50 & \multirow{2}{*}{1344.50} & \multirow{2}{*}{-0.33} & \multirow{2}{*}{0.739} & \multirow{2}{*}{-} \\
\hline & $20 \geq$ & 189 & 102.89 & 19445.50 & & & & \\
\hline \multirow{2}{*}{ EDE } & $\geq 19$ & 14 & 53.64 & 751.00 & \multirow{2}{*}{646.00} & 318 & $0001 * \%$ & 093 \\
\hline & $20 \geq$ & 188 & 105.06 & 19752.00 & & -3.18 & $0.001 *$ & 0.23 \\
\hline
\end{tabular}

Tabloda görüldüğü üzere, yaş değişkeni, ölçeğin iki alt boyutu (Analitiklik ve Meraklılık) ve geneli bakımından anlamlı bir farklılaşmaya neden olmaktadır.

Tablo 17

Müzik Öğretmeni Adaylarının EDE Düzeylerinin Cinsiyete Göre Karşılaştırılmasına Yönelik T-Testi (N=204)

\begin{tabular}{|c|c|c|c|c|c|c|c|c|}
\hline \multirow{2}{*}{ Ölçek } & \multirow{2}{*}{ Cinsiyet } & \multicolumn{3}{|c|}{ Betimsel İst. } & \multicolumn{3}{|c|}{ t-Test } & \multirow{2}{*}{ Etki Düzeyi $(d)$} \\
\hline & & $n$ & $\overline{\mathbf{X}}$ & Ss & $t$ & $s d$ & $P$ & \\
\hline \multirow{2}{*}{ Analitiklik } & Kadın & 129 & 45.22 & 5.98 & \multirow{2}{*}{0.42} & \multirow{2}{*}{202} & \multirow{2}{*}{0.672} & \multirow[b]{2}{*}{-} \\
\hline & Erkek & 75 & 44.85 & 5.80 & & & & \\
\hline \multirow{2}{*}{ Açık fikirlilik } & Kadın & 129 & 39.64 & 8.36 & \multirow{2}{*}{0.77} & \multirow{2}{*}{201} & \multirow{2}{*}{0.441} & \multirow{2}{*}{-} \\
\hline & Erkek & 74 & 38.66 & 9.26 & & & & \\
\hline \multirow{2}{*}{ Meraklılık } & Kadın & 129 & 45.71 & 6.87 & \multirow{2}{*}{0.85} & \multirow{2}{*}{202} & \multirow{2}{*}{0.398} & \multirow[b]{2}{*}{-} \\
\hline & Erkek & 75 & 46.53 & 6.38 & & & & \\
\hline \multirow{2}{*}{ Kendine güven } & Kadın & 129 & 42.97 & 7.03 & \multirow{2}{*}{0.41} & \multirow{2}{*}{202} & \multirow{2}{*}{0.679} & \multirow[b]{2}{*}{-} \\
\hline & Erkek & 75 & 43.37 & 6.11 & & & & \\
\hline \multirow{2}{*}{ Doğruyu arama } & Kadın & 128 & 33.94 & 7.26 & \multirow{2}{*}{0.10} & \multirow{2}{*}{201} & \multirow{2}{*}{0.920} & \multirow{2}{*}{-} \\
\hline & Erkek & 75 & 34.06 & 9.25 & & & & \\
\hline \multirow{2}{*}{ Sistematiklik } & Kadın & 129 & 40.57 & 7.77 & \multirow{2}{*}{0.18} & \multirow{2}{*}{202} & \multirow{2}{*}{0.859} & \multirow{2}{*}{-} \\
\hline & Erkek & 75 & 40.78 & 8.62 & & & & \\
\hline \multirow{2}{*}{ EDE } & Kadın & 128 & 247.88 & 26.74 & \multirow{2}{*}{0.01} & 200 & 0.996 & - \\
\hline & Erkek & 74 & 247.86 & 29.88 & & 200 & 0.990 & - \\
\hline
\end{tabular}

Tabloda görüldüğü üzere, cinsiyet değişkeni anlamlı bir farka neden olmamaktadır ( $\mathrm{p}>.05)$. Gruplara ait ortalama puanlar incelendiğinde, kadın ve erkek müzik öğretmeni adaylarının benzer EDE’ne sahip oldukları anlaşılmaktadır.

Tablo 18

Müzik Öğretmeni Adaylarının EDE Düzeylerinin Mezun Oldukları Lise Türüne Göre Karşılaştırılmasına Yönelik Kruskal-Wallis H Testi ( $\mathrm{N}=204)$

\begin{tabular}{|c|c|c|c|c|c|c|c|c|}
\hline \multirow{2}{*}{ Boyut/Ölçek } & \multirow{2}{*}{ Mezun Olunan Lise } & \multicolumn{2}{|c|}{ Betimsel İst. } & \multicolumn{3}{|c|}{ Kruskal-Wallis } & \multirow{2}{*}{ M-W } & \multirow{2}{*}{ Etki $(d)$} \\
\hline & & n & Sira Ort. & $\mathbf{X}^{2}$ & sd & $\mathbf{p}$ & & \\
\hline \multirow{3}{*}{ Analitiklik } & Konservatuvar (1) & 7 & 111,79 & & & & & \\
\hline & GSL (2) & 161 & 104,00 & 1.03 & 2 & 0.599 & - & - \\
\hline & Diğer (3) & 36 & 94,00 & & & & & \\
\hline \multirow{3}{*}{ Açık fikirlilik } & Konservatuvar (1) & 7 & 105,29 & & & & & \\
\hline & GSL (2) & 161 & 106,23 & 7.97 & 2 & $0.033^{*}$ & 1,2 ile 3 & 0.35 \\
\hline & Diğer (3) & 35 & 81,89 & & & & & \\
\hline \multirow{3}{*}{ Meraklılık } & Konservatuvar (1) & 7 & 85,71 & & & & & \\
\hline & GSL (2) & 161 & 104,89 & 1.41 & 2 & 0.495 & - & - \\
\hline & Diğer (3) & 36 & 95,07 & & & & & \\
\hline
\end{tabular}


Tablo 18 'in devamı

\begin{tabular}{|c|c|c|c|c|c|c|c|c|}
\hline \multirow{2}{*}{ Boyut/Ölçek } & \multirow{2}{*}{ Mezun Olunan Lise } & \multicolumn{2}{|c|}{ Betimsel İst. } & \multicolumn{3}{|c|}{ Kruskal-Wallis } & \multirow{2}{*}{ M-W } & \multirow{2}{*}{ Etki $(d)$} \\
\hline & & $\mathbf{n}$ & Sira Ort. & $\mathbf{X}^{2}$ & sd & $\mathbf{p}$ & & \\
\hline \multirow{3}{*}{ Kendine güven } & Konservatuvar (1) & 7 & 124,64 & & & & & \\
\hline & GSL (2) & 161 & 105,06 & 3.88 & 2 & 0.143 & - & - \\
\hline & Diğer (3) & 36 & 86,74 & & & & & \\
\hline \multirow{3}{*}{ Doğruyu arama } & Konservatuvar (1) & 6 & 103,08 & & & & & \\
\hline & GSL (2) & 161 & 108,13 & 9.07 & 2 & $0.011 *$ & 1,2 ile 3 & 0.38 \\
\hline & Diğer (3) & 36 & 75,72 & & & & & \\
\hline \multirow{3}{*}{ Sistematiklik } & Konservatuvar (1) & 7 & 100,71 & & & & & \\
\hline & GSL (2) & 161 & 107,34 & 8.80 & 2 & $0.025^{*}$ & 1,2 ile 3 & 0.37 \\
\hline & Diğer (3) & 36 & 81,22 & & & & & \\
\hline \multirow{3}{*}{ EDE } & Konservatuvar (1) & 6 & 101,25 & & & & & \\
\hline & GSL (2) & 161 & 107,78 & 10.39 & 2 & $0.006 * *$ & 1,2 ile 3 & 0.42 \\
\hline & Diğger (3) & 35 & 72,64 & & & & & \\
\hline
\end{tabular}

Tabloda görüldüğü üzere, mezun olunan lise, ölçeğin hem geneli hem de üç alt boyutu (Açık fikirlilik, Doğruyu arama ve Sistematiklik) bakımından da anlamlı bir farklılaşmaya neden olmaktadır.

Tablo 19

Müzik Öğretmeni Adaylarının EDE Düzeylerinin EDE ile İlgili Bilgi Düzeyine Göre Karşılaştırılmasına Yönelik Anova Testi $(\mathrm{N}=204)$

\begin{tabular}{|c|c|c|c|c|c|c|c|c|}
\hline \multirow{2}{*}{ Boyut/Ölçek } & \multirow{2}{*}{ ED ile İlgili Bilgi Düzeyi } & \multicolumn{3}{|c|}{ Betimsel İst. } & \multicolumn{2}{|c|}{ ANOVA } & \multirow{2}{*}{ Scheffe } & \multirow{2}{*}{ Etki $(\eta)$} \\
\hline & & $n$ & $\overline{\mathbf{X}}$ & Ss & $F$ & $\boldsymbol{P}$ & & \\
\hline \multirow{3}{*}{ Analitiklik } & Yetersiz (1) & 52 & 42.81 & 5.45 & & & & \\
\hline & Biraz yeterli (2) & 51 & 44.69 & 5.39 & 7.11 & $0.001 * *$ & 1 ile 3 & 0.26 \\
\hline & Yeterli (3) & 101 & 46.46 & 6.03 & & & & \\
\hline \multirow{3}{*}{ Açık fikirlilik } & Yetersiz (1) & 52 & 38.19 & 9.12 & & & & \\
\hline & Biraz yeterli (2) & 51 & 39.04 & 8.01 & 0.75 & 0.475 & - & - \\
\hline & Yeterli (3) & 100 & 39.97 & 8.81 & & & & \\
\hline \multirow{3}{*}{ Meraklılık } & Yetersiz (1) & 52 & 44.21 & 6.59 & & & & \\
\hline & Biraz yeterli (2) & 51 & 45.34 & 5.44 & 4.09 & $0.018 *$ & 1 ile 3 & 0.20 \\
\hline & Yeterli (3) & 101 & 47.28 & 7.09 & & & & \\
\hline \multirow{3}{*}{ Kendine güven } & Yetersiz (1) & 52 & 41.79 & 5.96 & & & & \\
\hline & Biraz yeterli (2) & 51 & 42.41 & 6.15 & 2.58 & 0.079 & - & - \\
\hline & Yeterli (3) & 101 & 44.16 & 7.19 & & & & \\
\hline \multirow{3}{*}{ Doğruyu arama } & Yetersiz (1) & 52 & 32.83 & 7.18 & & & & \\
\hline & Biraz yeterli (2) & 50 & 34.11 & 7.91 & 0.76 & 0.469 & - & - \\
\hline & Yeterli (3) & 101 & 34.51 & 8.51 & & & & \\
\hline \multirow{3}{*}{ Sistematiklik } & Yetersiz (1) & 52 & 38.94 & 7.03 & & & & \\
\hline & Biraz yeterli (2) & 51 & 40.00 & 9.08 & 2.48 & 0.087 & - & - \\
\hline & Yeterli (3) & 101 & 41.85 & 7.92 & & & & \\
\hline \multirow{3}{*}{ EDE } & Yetersiz (1) & 52 & 238.76 & 24.86 & & & & \\
\hline & Biraz yeterli (2) & 50 & 245.12 & 25.01 & 5.69 & $0.004 * *$ & 1 ile 3 & 0.23 \\
\hline & Yeterli (3) & 100 & 253.99 & 29.37 & & & & \\
\hline
\end{tabular}

Tabloda görüldüğü üzere, eleştirel düşünme ile ilgili bilgi düzeyi, ölçeğin geneli ve iki alt boyutu (Analitiklik ve Meraklılık) bakımından anlamlı bir farklılaşmaya neden olmaktadır.

Tablo 20

Müzik Öğretmeni Adaylarının EDE Düzeylerinin DZ ile İlgili Bilgi Düzeyine Göre Karşılaştırılmasına Yönelik Anova Testi $(\mathrm{N}=204)$

\begin{tabular}{|c|c|c|c|c|c|c|c|c|}
\hline \multirow{2}{*}{ Boyut/Ölçek } & \multirow{2}{*}{$\begin{array}{l}\text { DZ ile İlgili Bilgi } \\
\text { Düzeyi }\end{array}$} & \multicolumn{3}{|c|}{ Betimsel İst. } & \multicolumn{2}{|c|}{ ANOVA } & \multirow{2}{*}{ Scheffe } & \multirow{2}{*}{ Etki $(\eta)$} \\
\hline & & $n$ & $\overline{\mathbf{X}}$ & ss & $F$ & $p$ & & \\
\hline \multirow{3}{*}{ Analitiklik } & Yetersiz (1) & 42 & 43.71 & 5.26 & & & & \\
\hline & Biraz yeterli (2) & 49 & 45.31 & 5.74 & 1.45 & 0.238 & - & - \\
\hline & Yeterli (3) & 113 & 45.50 & 6.17 & & & & \\
\hline \multirow{3}{*}{ Açık fikirlilik } & Yetersiz (1) & 42 & 37.88 & 9.46 & & & & \\
\hline & Biraz yeterli (2) & 49 & 39.52 & 7.49 & 0.70 & 0.499 & - & - \\
\hline & Yeterli (3) & 112 & 39.70 & 8.89 & & & & \\
\hline \multirow{3}{*}{ Meraklılık } & Yetersiz (1) & 42 & 44.74 & 5.81 & & & & \\
\hline & Biraz yeterli (2) & 49 & 45.58 & 5.44 & 1.43 & 0.241 & - & - \\
\hline & Yeterli (3) & 113 & 46.68 & 7.41 & & & & \\
\hline \multirow{3}{*}{ Kendine güven } & Yetersiz (1) & 42 & 42.01 & 6.29 & & & & \\
\hline & Biraz yeterli (2) & 49 & 41.37 & 6.88 & 4.09 & $0.018^{*}$ & 1 ile 3 & 0.20 \\
\hline & Yeterli (3) & 113 & 44.29 & 6.58 & & & & \\
\hline
\end{tabular}


Tablo 20'nin devamı

\begin{tabular}{|c|c|c|c|c|c|c|c|c|}
\hline \multirow{2}{*}{ Boyut/Ölçek } & \multirow{2}{*}{ DZ ile İlgili Bilgi Düzeyi } & \multicolumn{3}{|c|}{ Betimsel İst. } & \multicolumn{2}{|c|}{ ANOVA } & \multirow{2}{*}{ Scheffe } & \multirow{2}{*}{ Etki $(\eta)$} \\
\hline & & $n$ & $\overline{\mathbf{X}}$ & ss & $F$ & & & \\
\hline \multirow{3}{*}{ Doğruyu arama } & Yetersiz (1) & 42 & 32.21 & 7.16 & & & & \\
\hline & Biraz yeterli (2) & 49 & 33.15 & 7.74 & 2.24 & 0.110 & - & - \\
\hline & Yeterli (3) & 112 & 35.01 & 8.37 & & & & \\
\hline \multirow{3}{*}{ Sistematiklik } & Yetersiz (1) & 42 & 38.33 & 7.86 & & & & \\
\hline & Biraz yeterli (2) & 49 & 39.39 & 8.12 & 4.15 & $0.017 *$ & 1 ile 3 & 0.20 \\
\hline & Yeterli (3) & 113 & 42.05 & 7.91 & & & & \\
\hline \multirow{3}{*}{ EDE } & Yetersiz (1) & 42 & 238.88 & 22.58 & & & & \\
\hline & Biraz yeterli (2) & 49 & 244.31 & 27.12 & 4.51 & $0.012 *$ & 1 ile 3 & 0.21 \\
\hline & Yeterli (3) & 111 & 252.85 & 29.08 & & & & \\
\hline
\end{tabular}

$* p<.05$

Tabloda görüldüğü üzere, eleştirel düşünme ile ilgili bilgi düzeyi, ölçeğin geneli ve iki alt boyutu (Kendine güven ve Sistematiklik) bakımından anlamlı bir farklılaşmaya neden olmaktadır.

Tablo 21

Müzik Öğretmeni Adaylarının EDE Düzeylerinin Demografik Özelliklerine Göre Karşılaştırılmasına Yönelik Özet Tablo

\begin{tabular}{|c|c|c|c|c|c|c|c|}
\hline \multirow[b]{2}{*}{ Değişken/Ölçek } & \multicolumn{7}{|c|}{ EDE Ölçeği } \\
\hline & Analitiklik & $\begin{array}{c}\text { Açık } \\
\text { fikirlilik }\end{array}$ & Meraklılık & $\begin{array}{l}\text { Kendine } \\
\text { güven }\end{array}$ & $\begin{array}{c}\text { Doğruyu } \\
\text { arama }\end{array}$ & Sistematiklik & $\begin{array}{c}\text { Ölçek } \\
\text { (Genel) }\end{array}$ \\
\hline Yaş & $* *$ & Fark yok & $*$ & Fark yok & Fark yok & Fark yok & $* *$ \\
\hline Cinsiyet & Fark yok & Fark yok & Fark yok & Fark yok & Fark yok & Fark yok & Fark yok \\
\hline Mezun olunan lise & Fark yok & $*$ & Fark yok & Fark yok & $*$ & $*$ & $* *$ \\
\hline ED eğilimi ile ilgili b. & $* *$ & Fark yok & * & Fark yok & Fark yok & Fark yok & $* *$ \\
\hline DZ ile ilgili bilgi b. & Fark yok & Fark yok & Fark yok & * & Fark yok & $*$ & $*$ \\
\hline
\end{tabular}

Fark $* p<.05, * * p<.01, * * * p<.001$ düzeyinde anlamlıdır.

Araştırmaya katılan müzik öğretmeni adaylarının EDE düzeylerinin demografik özelliklerine göre farklılaşmalarını özetlemek gerekirse (Tablo 21); öğrencilerin yaşı, mezun oldukları lise, EDE ile ilgili bilgi düzeyi ve DZ ile ilgili bilgi düzeyi anlamlı farklılaşmaya neden olurken $(\mathrm{p}<.05)$, cinsiyet ile kısmen veya tamamen anlamlı bir farklılaşmaya neden olmamaktadır $(\mathrm{p}>.05)$.

\subsection{Müzik Öğretmeni Adaylarının DZ Düzeyleri ile EDE Düzeyleri Arasındaki İlișkilere Yönelik Bulgular}

Tablo 22

Müzik Öğretmeni Adaylarının DZ Düzeyleri ile EDE Düzeyleri Arasındaki İlişkiye Yönelik Korelasyon Katsayıları

\begin{tabular}{|c|c|c|c|c|c|}
\hline Boyut/Ölçek & & İyimserlik/Ruh H.D. & Duyguların değerlendirilmesi & Duyguların kullanımı & DZ (Genel) \\
\hline \multirow{2}{*}{ Analitiklik } & $r$ & $.310 * * *$ & $.168 *$ & 0.122 & $.217 * *$ \\
\hline & $p$ & 0.000 & 0.016 & 0.081 & 0.002 \\
\hline \multirow{2}{*}{ Açık fikirlilik } & $r$ & 0.105 & $.341 * * *$ & $.240 * *$ & 0.131 \\
\hline & $p$ & 0.135 & 0.000 & 0.001 & 0.063 \\
\hline \multirow{2}{*}{ Meraklılık } & $r$ & $.259 * * *$ & $.210 * *$ & 0.040 & $.272 * * *$ \\
\hline & $p$ & 0.000 & 0.003 & 0.573 & 0.000 \\
\hline \multirow{2}{*}{ Kendine güven } & $r$ & $.189 * *$ & 0.131 & 0.024 & $.186^{* *}$ \\
\hline & $p$ & 0.007 & 0.062 & 0.732 & 0.008 \\
\hline \multirow{2}{*}{ Doğruyu arama } & $r$ & 0.051 & $.247 * *$ & $.148^{*}$ & 0.096 \\
\hline & $p$ & 0.472 & 0.000 & 0.036 & 0.172 \\
\hline \multirow{2}{*}{ Sistematiklik } & $r$ & $.240 * *$ & $.460 * * *$ & 0.079 & $.403 * * *$ \\
\hline & $p$ & 0.001 & 0.000 & 0.262 & 0.000 \\
\hline \multirow{2}{*}{ EDE } & $r$ & $.286^{* * *}$ & $.428 * * *$ & $.173 *$ & $.344 * * *$ \\
\hline & $p$ & 0.000 & 0.000 & 0.014 & 0.000 \\
\hline
\end{tabular}

Tablo 22'de müzik öğretmeni adaylarının DZ düzeyleri ile EDE düzeyleri arasındaki ilişkileri incelemek üzere yapılan Pearson momentler çarpımı korelasyonuna ait katsayılar verilmiştir. Bulunan korelasyon katsayıları aşağıdaki kriterlere göre yorumlanmıştır.

\begin{tabular}{ll}
$\boldsymbol{r}$ & İlişki \\
\hline $0,00-0,10$ & Yok \\
$0,10-0,30$ & Zayıf \\
$0,30-0,50$ & Orta \\
$0,50-0,70$ & Güçlü \\
$0,70-1,00$ & Çok güçlü (Jawlik, 2016, s. 132) \\
\hline
\end{tabular}




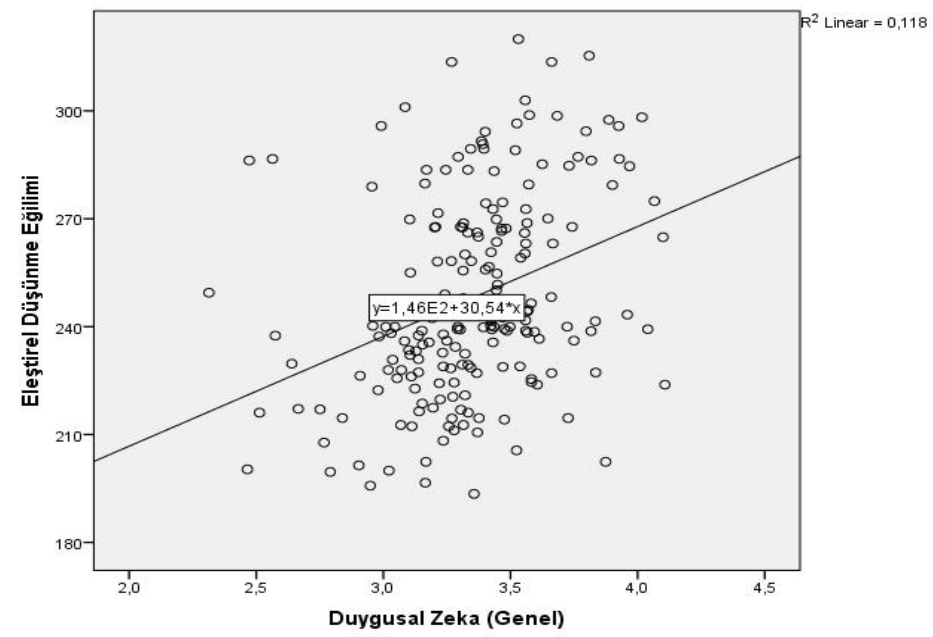

Şekil 3. Müzik öğretmeni adaylarının DZ düzeyleri ile EDE düzeyleri arasındaki ilişki

Tablodan görüldüğü üzere, müzik öğretmeni adaylarının, DZ düzeyleri ile EDE düzeyleri arasında pozitif yönlü ve "zayıf" ila "orta” düzeyde anlamlı ilişkiler olduğu tespit edilmiştir. Ölçek genel puanlarına göre bakıldığında;

a) EDE Düzeyi ile duyguların değerlendirilmesi arasında "orta" güçlükte, anlamlı ve pozitif bir ilişki varken ( $r$ Eleştirel Düşünme Eğilimi* Duyguların değerlendirilmesi $=0,428 ; p<.001)$, Iyimserlik/Ruh H.D. ( $r$ Eleștirel Düşünme Eğilimi* İyimserlik/Ruh H.D. $=0,286 ; p<.001)$ ve Duyguların kullanımı ( $r$ Eleștirel Düşünme Eğilimi*Duyguların kullanımı $=0,173 ; p=0,014)$ arasında "zayıf" güçlükte, anlamlı ve pozitif bir ilişki vardır.

b) DZ Düzeyi ile Sistematiklik arasında "orta" güçlükte, anlamlı ve pozitif bir ilişki varken ( $r$ Duygusal Zekâ*Sistematiklik $=0,403 ; p<.001)$, Analitiklik ( $r$ Duygusal Zekâ*Analitiklik=0,217; $p=0,002)$, Meraklılık ( $r$ Duygusal Zekâ* Meraklı1ık $=0,272 ; p<.001$ ) ve Kendine güven ( $r$ Duygusal Zekâ*Kendine güven $=0,186 ; p=0,008)$ arasında "zayıf” güçlükte, anlamlı ve pozitif bir ilişki vardır.

c) Genel EDE düzeyi ile genel DZ düzeyi arasında ise "orta” güçlükte, anlamlı ve pozitif bir ilişki olduğu bulunmuştur ( $r$ Eleștirel Düşünme Eğilimi* Duygusal Zekâ $=0,344 ; p<.001)$. Buna göre, müzik öğretmeni adaylarının EDE düzeyi (puanları) arttıkça DZ düzeyleri de artmaktadır (veya tersi).

\section{Sonuç, Tartışma ve Öneriler}

\subsection{Müzik Öğretmeni Adaylarının DZ Düzeylerine Yönelik Sonuçlar ve Tartışma}

Müzik öğretmeni adaylarının (genel) DZ puanları orta düzey olarak tespit edilmiștir. “DZ Ölçeği”nin alt boyutlarına yönelik puanlarına bakıldığında ise müzik öğretmeni adaylarının en yüksek ortalama puanı iyimserlik/ruh halinin düzenlenmesi alt boyutu için verdikleri, bunu sırasıly duyguların değerlendirilmesi ve duyguların kullanımı alt boyutlarının takip ettiği görülmüştür. Sonuçlar birlikte değerlendirildiğinde, araştırmaya katılan müzik öğretmeni adaylarının kendi algılarına göre DZ düzeylerinin orta seviyede olduğu anlaşılmaktadır.

Araştırmaya katılan müzik öğretmeni adaylarının, demografik özelliklerine bağlı olarak DZ düzeylerinde (puanlarında) farklılaşma olup olmadığına yönelik sonuçlar aşağıda sunulmuştur:

a) Müzik öğretmeni adaylarının DZ düzeyleri/puanları yaşa bağlı olarak ölçeğin bir alt boyutu (İyimserlik/Ruh halinin düzenlenmesi) ve geneli bakımından anlamlı bir farklılaşmaya neden olmaktadır. Buna göre; yaşı 20 ve üstünde olan öğrencilerin iyimserlik/ruh halinin düzenlenmesi düzeyleri ile (genel) DZ düzeyleri, yaşı 19 ve altında olan öğrencilerden daha yüksektir.

b) Müzik öğretmeni adaylarının DZ düzeylerinin/puanlarının cinsiyete bağlı olarak ölçeğin sadece duyguların değerlendirilmesi alt boyutu bakımından anlamlı bir farklılaşmaya neden olduğu ve bu farkın kadın öğrenciler lehine olduğu bulunmuştur. Kadın öğrencilerin DZ'nin duyguların değerlendirilmesi düzeylerinin erkek öğrencilerden daha yüksek olduğu bulunmuştur.

c) Müzik öğretmeni adaylarının DZ düzeylerinin/puanlarının mezun oldukları lise türüne bağlı olarak ölçeğin geneli ve iki alt boyutu bakımından anlamlı bir farklılaşmaya neden olduğu bulunmuştur. Buna göre; konservatuvar mezunu öğrencilerin iyimserlik/ruh halinin düzenlenmesi ve duyguların değerlendirilmesi düzeyleri "Diğer" liselerden mezun öğrencilerden daha yüksektir. Müzik öğretmeni adaylarının (genel) DZ düzeylerinin de mezun oldukları lise türüne göre anlamlı bir farklılık gösterdiği ve konservatuvar mezunu öğrencilerin DZ düzeylerinin, GSL ve "Diğer" liselerden mezun öğrencilerden daha yüksek olduğu bulunmuştur. 
d) Müzik öğretmeni adaylarının DZ düzeylerinin/puanlarının eleştirel düşünme ile ilgili bilgi düzeyine bağlı olarak anlamlı bir farklılık gösterdiği, eleştirel düşünme ile ilgili bilgi düzeyi yeterli olan öğrencilerin iyimserlik/ruh halinin düzenlenmesi düzeylerinin, eleştirel düşünme ile ilgili bilgi düzeyi yetersiz ve biraz yetersiz olan öğrencilerden daha yüksek olduğu bulunmuştur.

e) Müzik öğretmeni adaylarının, DZ ile ilgili bilgi düzeyine bağlı olarak DZ düzeylerinin anlamlı bir farklılık gösterdiği, DZ ile ilgili bilgi düzeyi yeterli olan öğrencilerin duyguların düzenlenmesi ve (genel) DZ düzeylerinin, DZ ile ilgili bilgi düzeyi yetersiz ve biraz yetersiz olan öğrencilerden daha yüksek olduğu bulunmuştur.

Mayer, Caruso ve Salovey (1999) de kadınların DZ'lerinin yüksek olmalarındaki sebebi kadınların toplumda daha az güç sahibi oldukları için duyguları daha dikkatli okumak zorunda oldukları olarak ifade etmektedir (Aşan ve Özyer, 2003, s. 163). Yapmış olduğumuz araştırmayla paralellik göstermektedir.

Araştırmada, konservatuvardan mezun olan öğrencilerin DZ düzeylerinin GSL ve "Diğer" liselerden mezun öğrencilerden daha yüksek olduğu görülmüştür. Bu noktada, konservatuvardan mezun olan öğrencilerin çalg1 çalışma sürelerinin fazla olmasından kaynaklı olarak duygularını çeşitli birçok sanat eseriyle ortaya koymalarının, kendi duygularını anlama becerilerini geliştirdiği düşünülebilir.

\subsection{Müzik Öğretmeni Adaylarının EDE Düzeylerine Yönelik Sonuçlar ve Tartışma}

Araştırmaya katılan müzik öğretmeni adaylarının (genel) EDE orta düzeyde bulunmuştur. "EDE Ölçeği”nin alt boyutlarına yönelik ortalama puanlara bakıldığında, müzik öğretmeni adaylarının en yüksek ortalama puanının meraklılık alt boyutu için bulunduğu görülmektedir. Meraklılık alt boyutunu sırasıly analitiklik, kendine güven, sistematiklik, açık fikirlilik ve doğruyu arama alt boyutları takip etmektedir. Sonuçlar birlikte değerlendirildiğinde, araştırmaya katılan müzik öğretmeni adaylarının kendi algılarına göre EDE düzeylerinin orta seviyede olduğu anlaşılmaktadır.

Araştırmaya katılan müzik öğretmeni adaylarının demografik özelliklerine bağlı olarak EDE düzeylerinde (puanlarında) farklılaşma olup olmadığına yönelik sonuçlar aşağıda sunulmuştur:

a) Müzik öğretmeni adaylarının EDE düzeylerinin/puanlarının yaşa bağlı olarak anlamlı bir farklılık gösterdiği, yaşı 20 ve üstünde olan öğrencilerin analitiklik, meraklılık ve (genel) EDE düzeylerinin, yaşı 19 ve altında olan öğrencilerden daha yüksek olduğu bulunmuştur.

b) Müzik öğretmeni adaylarının EDE düzeylerinin/puanlarının cinsiyete bağlı olarak anlamlı bir farklılık göstermediği bulunmuştur $(\mathrm{p}<.05)$.

c) Müzik öğretmeni adaylarının EDE düzeylerinin/puanlarının mezun oldukları lise türüne bağlı olarak anlamlı bir farklılık gösterdiği, konservatuvar ve GSL mezunu öğrencilerin açık fikirlilik, doğruyu arama, sistematiklik ve (genel) EDE düzeylerinin "Diğer" liselerden mezun öğrencilerden daha yüksek olduğu bulunmuştur.

d) Müzik öğretmeni adaylarının EDE düzeylerinin/puanlarının eleştirel düşünme ile ilgili bilgi düzeyine bağlı olarak anlamlı bir farklılık gösterdiğgi, eleştirel düşünme ile ilgili bilgi düzeyi yeterli olan öğrencilerin analitiklik, meraklılık ve (genel) EDE düzeylerinin, eleştirel düşünme ile ilgili bilgi düzeyi yetersiz olan öğrencilerden daha yüksek olduğu bulunmuştur.

e) Müzik öğretmeni adaylarının EDE düzeylerinin/puanlarının DZ ile ilgili bilgi düzeyine bağlı olarak anlamlı bir farklılık gösterdiği, DZ ile ilgili bilgi düzeyi yeterli olan öğrencilerin kendine güven, sistematiklik ve (genel) EDE düzeylerinin, DZ ile ilgili bilgi düzeyi yetersiz olan öğrencilerden daha yüksek olduğu bulunmuştur.

Yaman ve Yalçın (2004), Kökdemir (2003), Özdemir'in (2005) yapmış oldukları araştırmalarında, eleştirel düşünme eğilimleri düzeyleri ile cinsiyet arasında benzer bulgulara ulaşılmıştır.

Şen'in (2009), Dutoğlu ve Tuncel'in (2008) ve Piji Küçük'ün (2013) yapmış oldukları araştırmalarında, eleştirel düşünme eğilimlerinin, müzik öğretmeni adaylarının eğitim gördükleri kurumlara bağlı olarak benzerlik gösterdiği görülmektedir. Eldeki araştırma bulguları, diğer araştırmacıların bulgularını destekler niteliktedir.

Yapılan araştırmada 20 yaş üzeri olan öğrencilerin EDE düzeylerinin yüksek olmasının kişinin yaş aldıkça daha sorgulayıcı ve eleștirel olmasından, kendisinin farkında olup etik davranışlar sergileyebilmesi için davranışlarını belli süzgeçlerden geçirebilmesinden kaynaklı olabileceği düşünülebilir. Bireysel çalgı değişkeni ile ilgili bire bir sayıda yeterli alan çalışmasının olmaması bu konuda kesin bir genelleme yapabilmeye imkân tanımamaktadır. Bireysel çalgı değişkeni ile ilgili daha heterojen bir grupla bu hipotezin tekrar sınanmasının faydalı olacağı düşünülmektedir. 


\subsection{Müzik Öğretmeni Adaylarının DZ Düzeyleri ile EDE Düzeyleri Arasındaki İlişsilere Yönelik Sonuçlar ve Tartışma}

Müzik öğretmeni adaylarının DZ düzeyleri ile EDE düzeyleri arasında pozitif yönlü ve "zayıf” ile “orta” düzeyde anlamlı ilişkiler olduğu tespit edilmiştir. Ölçek genel puanlarına göre bakıldığında;

a) EDE Düzeyi ile duyguların değerlendirilmesi arasında "orta" güçlükte, anlamlı ve pozitif bir ilişki varken, Iyimserlik/Ruh H.D. ve Duyguların kullanımı arasında "zayıf” güçlükte, anlamlı ve pozitif bir ilişki vardır.

b) DZ Düzeyi ile Sistematiklik arasında “orta” güçlükte, anlamlı ve pozitif bir ilişki varken, Analitiklik, Meraklılık ve Kendine güven arasında "zayıf” güçlükte, anlamlı ve pozitif bir ilişki vardır.

c) Genel EDE düzeyi ile genel DZ düzeyi arasında ise "orta" güçlükte, anlamlı ve pozitif bir ilişki olduğu bulunmuştur. Buna göre, müzik öğretmeni adaylarının EDE düzeyi (puanları) arttıkça DZ düzeyleri de artmaktadır (veya tersi).

Dutoğlu ve Tuncel'in (2008) çalışmasındaki sonuca göre, beden eğitimi öğretmen adaylarının eleştirel düşünme eğilimlerinin alt ölçekleri ile DZ alt boyutları arasında benzerlik gösterdiği görülmektedir. Certel, Çatıkkaş ve Yalçınkaya (2011) çalışmasındaki sonuca göre, aday öğretmenlerin DZ düzeyleri ile eleştirel düşünme eğilimleri arasında orta düzeyde pozitif yönde anlamlı bir ilişki olduğu ve bulunan sonuçlarla örtüştüğü görülmektedir. Gürşen Otacioğlu'nun (2009) Marmara Üniversitesi Atatürk Eğitim Fakültesinde öğrenim gören müzik öğretmeni adaylarıyla yapmış olduğu çalışmasında, Eğitim Fakültesi Güzel Sanatlar Bölümü öğrencilerinin DZ ölçeği puanlarının diğer bölümlerin öğrencilerinin DZ puanlarına göre daha yüksek çıktığ görülmektedir. Yapılan bu araştırmalarda DZ ve eleştirel düşünme eğilimleri arasında anlamlı bir ilişki olduğu ve müzik öğretmeni adaylarında DZ puanlarının yüksek çıktığı ve eldeki verilerin, yukarıdaki araştırma sonuçları ile paralellik gösterdiği görülmektedir. Bu noktada, bireylerin kendilerini fark edip, sorgulayıcı, eleştirel, yeni değişimlere ayak uydurabilen, problemlere çözüm üretebilen ve yanlışları tespit edebilen özellikleri kazanmalarının ve geliştirmelerinin onların bir o kadar motivasyonu yüksek, empati becerisi kuvvetli, kendini iyi ifade edebilir şekilde hayatlarına devam edebilmelerine katkı sağlayacağ

\section{4. Öneriler}

Araştırmanın sonuçları doğrultusunda, aşağıdaki öneriler gerekli ve yararlı görülmektedir:

\subsection{Müzik Öğretmeni Adaylarına Yönelik Öneriler}

- Müzik öğretmeni adaylarının EDE’yi pozitif yönde ilerletecek derslere yer verilmesi ve EDE düzeyini artmasına yönelik grup rehberliği etkinliklerinin yapılması önerilebilir.

- Müzik öğretmeni adaylarının, müfredatta içerisindeki derslerde eleştirel düşünme ile ilgili uygulamalı etkinliklerin yapılması önerilebilir.

\subsection{Eğitimcilere Yönelik Öneriler}

- Yapılan araştırmalardan da çıkan sonuçlara göre, aday öğretmenlerin DZ ve EDE düzeylerinin yeterince gelişmediği görülmektedir. Bu nedenle eğitimciler, DZ ve EDE kavramlarının önemi ve içeriği hakkında bilgilendirilebilir.

- $\quad$ DZ ve EDE'lerin eğitim programları içerisinde yer alması gerektiği önerilip öğretmenler tarafından teşvik edilebilir.

- $\quad$ Öğrencilere EDE gibi ayrı bir ders verilerek, bu becerilerin gelişiminin desteklenmesi gerektiği önerilebilir. Böylelikle eleştirel düşünme bir beceri öğretimi ve disiplinler arası yaklaşım olarak ele alındığı zaman, hem farklı disiplinler içerisinde konuların tekrarlanmasına gerek kalmaması hem de bilişsel bir beceri olarak tüm disiplinlerde kullanılabilmesi ve geliştirilebilmesi sağlanabilir.

- Eleştirel düşünme ve DZ gelişimi, bireyin hayatı boyunca devam eden bir süreç olduğundan dolayı iş hayatında hizmet içi eğitimler düzenlenebilir ve toplum bilinçlendirme programları hazırlanabilir.

- Eleştirel düşünme ve DZ kavramlarının gelişimi ilk olarak ailede başladığı için bu iki kavramın önemini içeren aile bilinçlendirme programlarının hazırlanması önerilebilir.

\subsection{Araştırmacılara Yönelik Öneriler}

- Eleştirel düşünme eğilimlerinin öğretimini kolaylaştıran öğretim, strateji, yöntem ve tekniklerinin tespit edilmesine yönelik araştırmaların yapılması önerilebilir.

- Yapılan bu araştırmanın farklı bölge ve okullarda uygulanarak genişletilmesi ve genellemeye imkân tanınması önerilebilir. 


\section{Kaynakça}

Akyüzlüer, F. (2014). Müzik öğretmeni eğitim programının müzik öğretmen adaylarının eleştirel düşünme becerileri üzerindeki etkileri. New World Sciences Academy-Fine Arts, 9(3), 111-119. doi: http://dx.doi.org/10.12739/NWSA.2014.9.3.D0152

Aşan, Ö., \& Özyer, K. (2003). Duygusal zekaya etki eden demografik faktörlerin saptanmasına yönelik ampirik bir çalışma. Hacettepe Üniversitesi İktisadi ve İdari Bilimler Fakültesi Dergisi, 21(1), 151-167. Erişim adresi: https://dergipark.org.tr/tr/download/article-file/309902

Certel, Z., Çatıkkaş, F., \& Yalçınkaya, M. (2011). Beden eğitimi öğretmen adaylarının duygusal zekâ ile eleştirel düşünme eğilimlerinin incelenmesi. Selçuk Üniversitesi Beden Eğitimi ve Spor Bilim Dergisi, 13(1), 74-81. Erişim adresi: https://www.researchgate.net/publication/330521022 Beden Egitimi Ogretmen Adaylarinin Duygusal_Zeka_ile_Elestirel_Dusunme_Egilimlerinin_Incelenmesi_Analysis_of the_Emotional_Intelligenc e_Levels_and_Critical_Thinking_Dispositions_of_Physical_Education_

Çelikkaya, H. (2009). Ĕgitim bilimlerine giriş-ĕgitimcilik ve öğretmenlik. Ankara: Nobel Yayın Dağıtım.

Çuhadar, H. (2006). Müziksel zekâ. Ulusal Müzik Eğitimi Sempozyumunda sunulan bildiri. Pamukkale Üniversitesi Eğitim Fakültesi, Denizli.

Demir, M. K. (2006). İlköğretim dördüncü ve beşinci sınıf ögrencilerinin sosyal bilgiler derslerinde eleştirel düşünme düzeylerinin çeşitli değişkenler açısından incelenmesi (Doktora Tezi). YÖK tez veri tabanından erişildi (Tez No. 187631).

Dutoğlu, G., \& Tuncel, M. (2008). Aday öğretmenlerin eleştirel düşünme eğilimleri ile duygusal zekâ düzeyleri arasındaki ilişki. Abant İzzet Baysal Üniversitesi Dergisi, 8(1), 11-32. Erişim adresi: https://dergipark.org.tr/tr/download/article-file/16602

Goleman, D. (2018). Duygusal zekâ neden IQ'dan daha önemlidir?. İstanbul: Varlık Yayınları.

Gürşen Otacığlu, S. (2009). Müzik öğretmeni adaylarının duygusal zekâ ile akademik ve çalgı başarı düzeyleri arasındaki ilişki. Fırat Üniversitesi Sosyal Bilimler Dergisi, 19(1), 85-96. Erişim adresi: http://web.firat.edu.tr/sosyalbil/dergi/arsiv/cilt19/sayi1/085-096.pdf

Jawlik, A. (2016). Statistics from A to Z. New Jersey: John Wiley \& Sons, Inc.

Karasar, N. (2017). Bilimsel araştırma yöntemi. Ankara: Nobel Akademik Yayıncılık.

Kökdemir, D. (2003). Belirsizlik durumlarında karar verme ve problem çözme (Doktora Tezi). YÖK tez veri tabanından erişildi (Tez No. 127649).

Mayer, J. D., Caruso, D. R., \& Salovey, P. (1999). Emotional intelligence meets traditional standarts for an intelligence. Intelligence, 22(1), 267-298. Erişim adresi: https://www.academia.edu/928082/Emotional_ Intelligence_Meets_Traditional_Standards_for_An_Intelligence

Norris, S. P. (1985). Synthesis of research on critical thinking. Educational Leadership, 8, 40-45. Erişim adresi: http://www.ascd.org/ASCD/pdf/journals/ed_lead/el_198505_norris.pdf

Özdemir, S. M. (2005). Üniversite öğrencilerinin eleştirel düşünme becerilerinin çeşitli değişkenler açısından değerlendirilmesi. Türk Eğitim Bilimleri Dergisi, 3(3), 297-316. Erişim adresi: https://dergipark.org.tr/tr/download/article-file/256389

Pektaş, S. (2013). Güzel sanatlar ve spor lisesi müzik bölümü ögrencileri ile diğer lise öğrencilerinin duygusal zekâ düzeylerinin karşılaştırılması (Yüksek Lisans Tezi). YÖK tez veri tabanından erişildi (Tez No. 333811).

Piji Küçük, D., \& Uzun, Y. B. (2013). Müzik öğretmeni adaylarının eleştirel düşünme eğilimleri. Ahi Evran Üniversitesi Kırşehir Eğitim Fakültesi Dergisi, 14(1), 327-345. Erişim adresi: http://kefad2.ahievran.edu.tr/archieve/pdfler/Cilt14Sayi1/JKEF_14_1_2013_327-345.pdf

Şen, Ü. (2009). Türkçe öğretmeni adaylarının eleştirel düşünme tutumlarının çeşitli değişkenler açısından değerlendirilmesi. Journal of World of Turks, 1(2), 69-89. Erişim adresi: https://www.academia.edu/32143702/T\%C3\%BCrk\%C3\%A7e_\%C3\%96\%C4\%9Fretmeni_Adaylar $\% \mathrm{C} 4 \% \mathrm{~B}$ $1 \mathrm{n} \% \mathrm{C} 4 \% \mathrm{~B} 1 \mathrm{n}$ Ele $\% \mathrm{C} 5 \% 9$ Ftirel_D $\% \mathrm{C} 3 \% \mathrm{BC} \% \mathrm{C} 5 \% 9 \mathrm{~F} \% \mathrm{C} 3 \% \mathrm{BC}$ me Tutumlar $\% \mathrm{C} 4 \% \mathrm{~B} 1 \mathrm{n} \% \mathrm{C} 4 \% \mathrm{~B} 1 \mathrm{n} \_\mathrm{C} 3$ $\% 87 \mathrm{e} \% \mathrm{C} 5 \% 9 \overline{\mathrm{Fitli}} \mathrm{De} \% \mathrm{C} 4 \% 9 \mathrm{Fi} \% \mathrm{C} 5 \% 9$ Fkenler_A $\% \mathrm{C} 3 \% \mathrm{~A} 7 \% \mathrm{C} 4 \% \overline{\mathrm{B}} 1 \mathrm{~s} \% \mathrm{C} 4 \% \mathrm{~B} 1 \mathrm{ndan} \_\mathrm{De} \% \mathrm{C} 4 \% 9 \mathrm{Ferlendir}$ ilmesi

Tufan, Ş. (2011). Geliştirilen duygusal zekâ ĕgitimi programının ortaöğretim dokuzuncu sinıf ögrencilerinin duygusal zekâ düzeylerine etkisi (Yüksek Lisans Tezi). YÖK tez veri tabanından erişildi (Tez No. 302910). 
Türkoğlu, A. (2005). 109 soruda öğretmenlik meslek bilgisine giriş. İstanbul: Kare Yayınları.

Uçan, A. (2015). Müzik ĕgitimi. Ankara: Evrensel Müzikevi Yayınları.

Yaman, S., \& Yalçın, N. (2004). Fen bilgisi öğretiminde probleme dayalı öğrenme yaklaşımının yaratıcı düşünme becerisine etkisi. Ilköğretim-Online, 4(1), 42-52. Erişim adresi: http://ilkogretimonline.org.tr/index.php/io/article/view/2022/1858 